\title{
第18回 中・四国肝臓病研究会
}

\author{
期 間：平成13年 9 月 8 日 \\ 会 場：岡山プラザホテル 4 階 \\ 顧 問：平山千里, 伊藤憲一, 島田宜浩, 山本泰猛 \\ 白木和夫，西岡幹夫，川崎寛中，梶山梧朗 \\ 世話人：辻 孝夫, 沖田 極, 伊束 進, 恩地森一 \\ 大西三朗, 山本晋一郎, 茶山一彰 \\ (平成14年 6 月 14 日受稿)

\section{主 題 I 自己免疫性肝炎} \\ 司 会：大西 三朗 (高知医科大学第一内科教授) \\ 恩地 森一 (愛媛大学医学部第三内科教授)
}

\section{1 ）急性肝炎様の発症を呈した自己免疫性肝炎の 3 症例}

岡本 良一, 白神 邦浩, 上田 直樹, 青井 則之
岡本 裕子, 石井 泰史, 河本 博文, 荒木 康之
野村 正博, 井上 純一

キーワード：自己免疫性肝炎, 急性肝炎

緒

言

自己免疫性肝炎 (AIH) は抗核抗体 (ANA) をはじめ とする自己抗体陽性で高 $\gamma$ グロブリン血症を特徵とす る慢性肝疾患である。 その発症様式の多くは潜行性発症 であるが，時に急性肝炎様の発症を呈する症例もある。 今回我々は急性肝炎椂の発症を呈し, 腹腔鏡下肝生検が 診断に有用であった $\mathrm{AIH} 3$ 症例を経験したので報告す る.

\section{対象と方法}

当院にて 2000 年 1 月以降 $\mathrm{AIH}$ と診断された症例の うち急性肝炎様の発症を呈した 3 症例を対象とした。過

指導：井上純一（社会保険広島市民病院内科）

論文請求先：补会保險広島市民病院内科

電話：082-221-2291
去に肝機能異常歴がなく発症後 ALT の最高値が 500 IU/ 1 以上に達した症例を急性肝炎様発症例と定義し た.

\section{症 例 1}

50 歳, 男性. 2000 年 3 月 AST 1146 IU/ 1, ALT 1529 IU/1 と肝機能異常あり, 急性肝炎として他院にて治療 していたが黄㾝, 肝機能異常が遷延し精查加療目的で 7 月 21 日当院入院.

\section{症 例 2}

55 歳, 女性. 2000 年 10 月急性肝炎として他院入院. T.Bil $10.5 \mathrm{mg} / \mathrm{dl}$, AST $1573 \mathrm{IU} / 1$, ALT $2550 \mathrm{IU} / 1$, ANA 80 倍陽性で AIH と診断されステロイド治療にて 軽快し退院. 2001 年 4 月再び肝機能検査の悪化あり 4 月 20 日当院入院. 


\section{症例 3}

44 歳, 男性. 2000 年 12 月検診にて肝機能異常, 高尿 酸血症を指摘され, アルコール性肝障害, 高尿酸血症と して近医にて治療されていた. 2000 年 3 月より約 1 ケ月 間ベンズブロマロンの服用歴あり。禁酒およびベンズブ ロマロン中止後 1 ヶ月経過後も肝機能検查の悪化あり 2001 年 5 月 21 日当院入院.

\section{結果}

3 症例の入院時検查成績を表 1 に示す(表 1 )。症例 3 では経過中に黄疸の出現はなかった。 3 症例とも ANA は低力価陽性または陰性であった，経過中 IgG が 2000 $\mathrm{mg} / \mathrm{dl}$ を超えたのは症例 2 のみであった. 3 症例とも入院 後 1 ヶ月以内に腹腔鏡下肝生検を施行した. 腹腔鏡所見 は, 肝表面がほほ平滑なものが 1 例(症例 2 )，広範陥山 を認めたものが 2 例(症例 $1 ， 3$ )であった. 溝状楩凹を 2 例(症例 1，2)に認めたが粗大起伏，粗大隆起，多小葉性 の赤色紋理はいずれの症例でも認められなかった。組織 学的には 3 例とも門脈域だけでなく中心静脈域の壊死炎 症所見が強かった(図 1 ). 症例 3 ではリンパ球の漫潤と ともに好酸球の浸潤も認め薬㓮性肝障害の関与も示唆さ れた. 3 症例ともプレドニゾロンまたはプレドニゾロン とウルソデオキシコール酸の併用療法により速やかに肝 機能の改善をみた。

\section{考察}

平成 9 年度厚生省難治性の肝炎研究班報告によると $\mathrm{AIH}$ 急性発症(重症型) 例は 1.7\%, AMA 陽性例は5.1\%

表 1 对象患者の入院時椧查成績

\begin{tabular}{lccc}
\hline & 症例 1 & 症例 2 & 症例 3 \\
\hline T. Bil (mg/dl) & 15.7 & 0.8 & 0.7 \\
D. Bil (mg/dl) & 10.1 & 0.2 & 0.2 \\
AST (IU/ l) & 265 & 247 & 227 \\
ALT (IU/ 1) & 372 & 631 & 442 \\
ALP (IU/ l) & 251 & 210 & 197 \\
$\gamma$-GTP (IU/ 1) & 142 & 80 & 60 \\
$\gamma$-glob (g/dl) & 1.57 & 1.43 & 1.13 \\
IgG (mg/dl) & 1,504 & 1,662 & 1,170 \\
IgM (mg/dl) & 631 & 193 & 62 \\
ANA & $(-)$ & $\times 40$ & $\times 40$ \\
ASMA & $\times 40$ & $\times 40$ & $(-)$ \\
AMA & $\times 320$ & $(-)$ & $(-)$ \\
HLA-DR & 2.6 & 2.4 & 4.6 \\
AIH スコア & 9 & 18 & 4 \\
\hline
\end{tabular}

前後とされている. 症例 1 については AMA 陽性であり PBC あるいは PBC-AIH オーバーラップ症候群との鑑 別が問題であったが組織学的に胆管病変は認められず $\mathrm{AIH}$ と診断した。このように AMA 陽性で $\boldsymbol{\gamma}$-グロブリ ン低值の $\mathrm{AIH}$ 症例の報告もあるので注意が必要であ る". 症例 3 についてはベンズブロマロンによる薬剤性 肝障害が病態を修飾している可能性があると考えられた が服用前より肝機能異常が出現しておりまた服用中止後 1 ケ月を経過しても肝機能が悪化していることより AIH と考えた。

腹腔鏡所見では広範陥凹，溝状陥凹などの陷凹所見が 主体であった。これらは組織学的には広範ないし覀広範 肝壊死などに対応した所見であり，肝表面から数小葉単 位の肝実質が壊死脱落することで形成されると考えられ る.また組織所見では架橋壊死圾よび閒脈域の炎症所見 のみならず中心静脈域の壊死炎症所見が特徴的であっ た.

AIH 急性発症例では抗核抗体陰性あるいは低力価例 が多く, $\gamma$-グロブリンも低值で, 自己免疫性肝炎の診断 基準を満たさない症例が多い233).したがって，ウィルス 性，特に非 B非C 型ウィルス性肝炎との鑑別診断が困難 であり，診断・治療に苦慮する症例もある。それらの中 には垔急性に経過し劇症化する危険性もあるので $\boldsymbol{\gamma}$-グ ロブリン低值例や AIH スコア低值例でも AIH に留意 することが重要であると考えられた。

\section{文献}

1) Shibata M, et al. : A case of autoimmune hepatitis with a high titer of antimitochondrial antibody and normal $\gamma$ -globulinemia. J Gastroenterology and Hepatology (2001) 16, 830-835.

2 ) 谷合麻紀子, 他：自己免疫性肝炎の臨床病理学的検討一 $\gamma$-グ ロブリン非上昇例を中心に一肝荿 (1999) 24，454-459.

3 ）松下栄紀, 他：自己免疫性肝炎における発症様式の検討. 肝臓 (1988) 39, 1357-1361. 

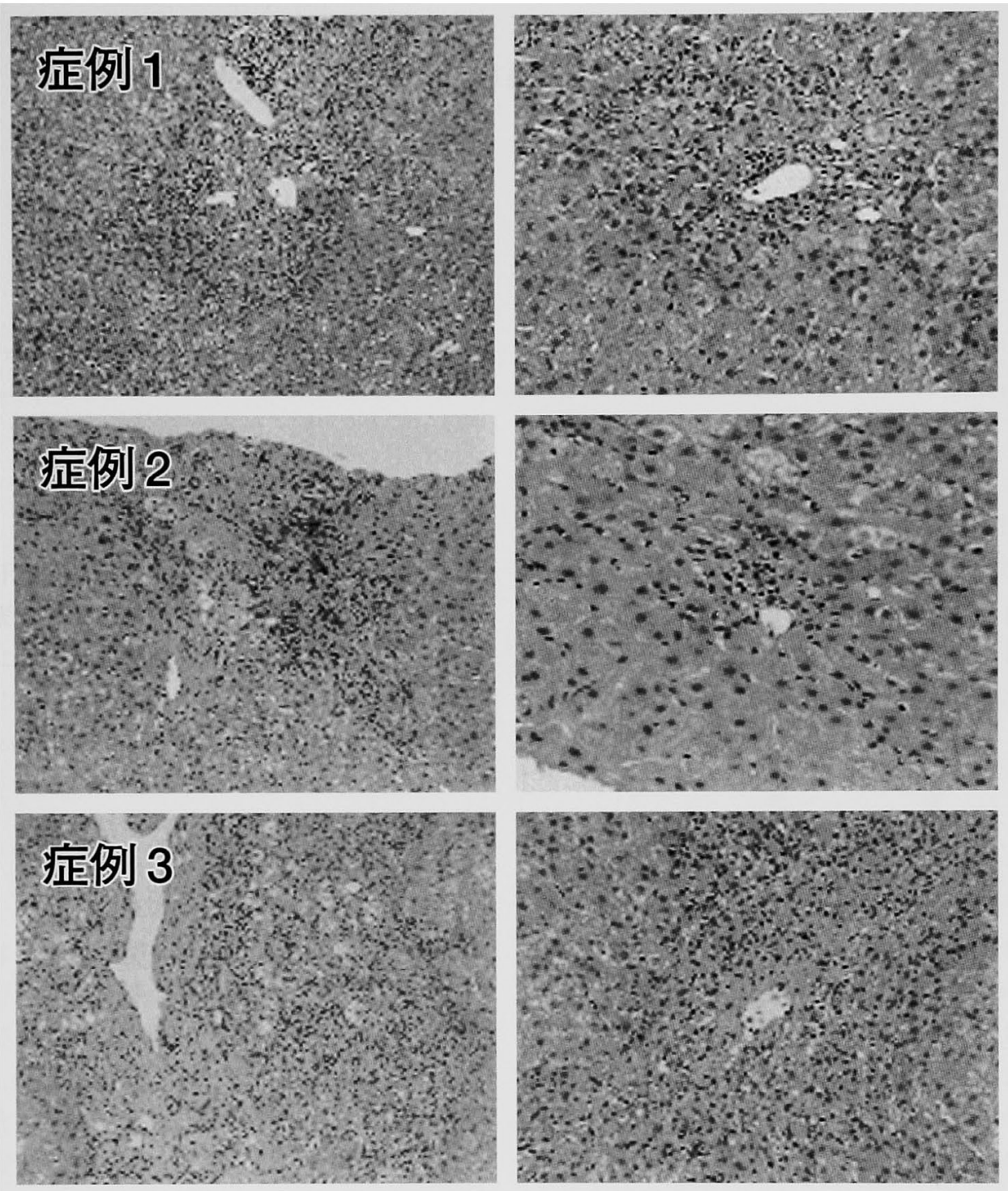

図 1 病理組織像 (HE 染色)

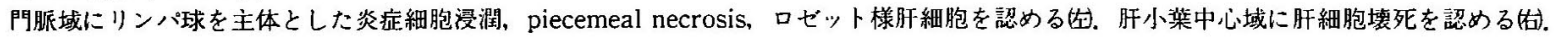


岡山医学会雑誌 第114巻

August 2002, pp. 193-194

2 ）劇症発症した自己免疫性肝炎の一例

萱野 幸三, 横山雄一郎, 草野 倫好, 岡本真理子

瀬川 誠, 坂口 栄樹, 坂井田 功, 沖田極

キーワード：自己免疫性肝炎, 劇症化

緒言

自己免疫性肝炎は一般的に増悪と寛解を繰り返しなが ら早期に肝硬変へと進展し得る慢性活動性肝炎である。 その発症様式には潜行発症型と急性発症型とがあるが, 劇症発症することは比較的稀であるとされている．今回 われわれは Basedow 病を合併し劇症発症した自己免疫 性肝炎（AIH）死亡例を経験したので報告する。

\section{症例}

症例は32歳，女性，主訴は全身倦急感および黄㾝，平 成12年10月頃より易疲労感を認めていたが放置. 平成13 年 1 月下旬より全身倦㤐感が顕著となり，2/19に知人か ら黄疸を指摘され $2 / 20$ に他医を受診, AST 1682, ALT 697, T-Bil 18.0, PT 37\%で急性肝炎重症型と診断され 同日当院入院となった。入院時現症としては意識は清明 で，皮屠および眼球結膜の黄染が著明. 眼球は突出し頝 部にびまん性に甲状腺腫を触知した。入院時検查所見と しては表 1 に示すとおりで，肝炎ウイルスマーカーは全 て陰性で, International AIH Scoring System で17点
で definite AIH と診断された，直ちにステロイド治療 を開始したが $2 / 25$ 肝性昏睡が出現し AIH の劇症化の診 断のもと血槳交換および持続血液滤過透析などを施行し

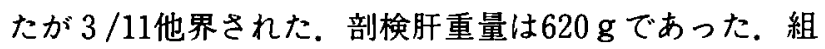
織像としては広範肝細胞壊死の所見を呈しており, 浸潤 炎症細胞についてはわずかに形質細胞を認めるものの大 半はリンパ球であった。

考察

AIH の劇症化は数\%と比較的稀であり，劇症化した場 合の予後は極めて不良であるとされており, 本症例も救 命することは出来なかった．本症例が劇症化した理由の 一つとして有症状にも関わらず医療機関の受診がなされ ず，無治療期間が約 5 力月もの長期にわたったことが考 之られた，急性肝炎の診断においては自己免疫性肝炎の 劇症化もあり得るということおよび劇症化した場合の子 後は極めて不良であるという点を常に念頭におき, International AIH Scoring System などを参考に早急な診断と 治療が必要であると考えられた。 
表 1 入院時検查所見

\begin{tabular}{|c|c|c|c|c|c|c|c|}
\hline \multicolumn{3}{|c|}{ Peripheral Blood } & \multicolumn{4}{|c|}{ Coagulation Test } & \multirow{2}{*}{$\begin{array}{l}\text { Thyroid Function } \\
\text { free T3 }(2.3-4.7)\end{array}$} \\
\hline WBC & 4,500 & $/ \mathrm{mm}^{3}$ & PT & 43 & $\%$ & & \\
\hline $\mathrm{RBC}$ & $414 \times 10^{4}$ & $/ \mathbf{m}^{3}$ & APTT & T 63 & $\%$ & & $15.6 \mathrm{pg} / \mathrm{ml}$ \\
\hline $\mathrm{Hb}$ & 8.5 & $g / d l$ & \multicolumn{3}{|c|}{ Serological Test } & \multicolumn{2}{|r|}{ free $\mathrm{T} 4(0.8-2.1)$} \\
\hline $\mathrm{Ht}$ & 26.1 & $\%$ & \multicolumn{3}{|c|}{$\operatorname{lgM}-\mathrm{HA}-\mathrm{Ab}$} & $(-)$ & $7.1 \mathrm{ng} / \mathrm{ml}$ \\
\hline Plt & $31.6 \times 10^{4}$ & mum & \multicolumn{3}{|c|}{$\mathrm{HBsAg}$} & $(-)$ & TSH $(0.43-4,95)$ \\
\hline \multicolumn{3}{|c|}{ Blood Chemistry } & \multicolumn{3}{|c|}{ HBsAb } & $(-)$ & $0.01 \mu \mathrm{U} / \mathrm{ml}$ \\
\hline $\mathrm{T}$-protein & 7.8 & $\mathrm{~g} / \mathrm{dl}$ & \multicolumn{3}{|c|}{$\operatorname{lgM}-\mathrm{HBc}-\mathrm{Ab}$} & $(-)$ & TGAB $\quad(<28.7)$ \\
\hline Alb & 3.0 & $\mathrm{~g} / \mathrm{dl}$ & \multicolumn{3}{|c|}{$\mathrm{HCV}-\mathrm{RNA}$} & $(-)$ & 359.7 IU \\
\hline globulin & 4.8 & $\mathrm{~g} / \mathrm{dl}$ & \multicolumn{3}{|c|}{ IgM-EBV VCA } & $(-)$ & HLA \\
\hline T-Chol & 108 & $\mathrm{mg} / \mathrm{dl}$ & \multicolumn{3}{|c|}{$\operatorname{lgM}-\mathrm{CMV}$} & $(-)$ & DR 8 \\
\hline ch-E & 61 & $\mathrm{IU} / \mathrm{I}$ & ANA & \multicolumn{2}{|l|}{$\times 100$} & $(+)$ & \multirow{2}{*}{$\begin{array}{l}\text { International AIH Group Scoring System } \\
15 \text { points (probable) }\end{array}$} \\
\hline AST & 1,781 & $\mathrm{IU} / 1$ & \multicolumn{3}{|c|}{ AMA } & $(-)$ & \\
\hline ALT & 727 & $\mathrm{IU} / \mathrm{I}$ & \multicolumn{3}{|l|}{ SMA } & $(-)$ & \\
\hline$\gamma$-GTP & 531 & $\mathrm{IU} / \mathrm{l}$ & RA & \multicolumn{2}{|c|}{$14.9 \mathrm{U} / \mathrm{ml}$} & $(+)$ & \\
\hline ALP & 843 & $\mathrm{IU} / \mathrm{I}$ & $\operatorname{lgg}$ & 3,100 & $\mathrm{mg} / \mathrm{dl}$ & & \\
\hline $\mathrm{LDH}$ & 725 & $\mathrm{IU} / 1$ & $\lg M$ & 215 & $\mathrm{mg} / \mathrm{dl}$ & & \\
\hline $\mathrm{T}$-Bil & 19.4 & $\mathrm{mg} / \mathrm{dl}$ & $\lg A$ & 369 & $\mathrm{mg} / \mathrm{dl}$ & & \\
\hline $\mathrm{D}-\mathrm{Bil}$ & 13.3 & $\mathrm{mg} / \mathrm{dl}$ & & & & & \\
\hline creatinine & 0.31 & $\mathrm{mg} / \mathrm{dl}$ & & & & & \\
\hline
\end{tabular}


岡山医学会雑誌 第114卷

August 2002, pp. 195-196

\section{3 ）急性発症した自己免疫性肝炎例の臨床的検討}

藤井 雅邦, 池田 弘, 藤原 大介, 藤井 澄

加藤 博也，足立 恵美，吉澤はづき，若林 肇

金吉 俊彦, 清野 哲司, 島村淳之輔

キーワード：自己免疫性肝炎（AIH）, 急性発症, 国際診断基準

緒言

近年, 自己免疫性肝炎 (AIH) における急性発症例が 注目されている。その臨床像を明らかにする目的で自験 例について検討を行った.



1995年以降，自己抗体，ウイルスマーカーが十分に検 索でき，AIH の国際診断基準（1999年）が確診の症例を 10例経験した．そのうち急性発症したものは 4 例 (40\%) であった．今回はその 4 例について臨床像を中心に検討 を行った。

成績

全例女性で，年齢は 41 歳，43歳，53歳，71歳と 1 例を 除き中年女性であった。

初発症状は黄㾝 2 例, 全身倦怠感 4 例であった. 全例, 自己免疫性疾患の既往はなく，1 例のみ家族歴で関節リ ウマチの合併を認めた。全例, 薬剤歴, 飲酒歴は認めな かった.

入院時の検查值では全例 ALT は700以上となり,T.Bil が10mg/dlを越えたものが2 例あった. 自己抗体は ANA， ASMA いずれかが陽性で160倍から640倍と高值を呈した。 AMA は全例陰性であった，HLA は検索できた 3 例全 例に DR 4 を認めた。

肝生検所見を表 1 に示す。1 例は重症化したため生検

指導：池田 弘（會数中央病院消化器内科）

論文請求先：倉教中央病院消化器内科

電話：086-422-0210
前にプレドニゾロン（PSL）を投与したが，他の 3 例で は PSL 投与前に生検を行い，著明な形質細胞の浸潤を 伴った活動性肝炎の像を認めた．また 3 例（生検前ステ ロイド使用例を含む）に中心静脈域に強い肝細胞壊死所 見および実質内に肥大したKupffer 細胞を認め, 急性肝 炎の像であった：もう1例はこれらの変化が軽度であり 潜在的に存在した AIH が急性増悪した可能性も考えら れた.

治療は全例, PSL を 30〜40mgから開始し, 著効が得 られた。長期経過で 2 例では PSL 中止後にも再燃がみ られず（うち1例では UDCA を継続），1例で10mgに減 量時点で再燃がみられた。再燃例は組織学的に慢性肝炎 の急性增悪が疑われた症例であった. また 1 例では UDCA， アザチオプリンの併用で PSL $4 \mathrm{mg}$ まで減量された.

$\mathrm{AIH}$ の国際診断基準（1999年）は生検前に PSL を投 与した 1 例が18点であった以外は 21 23点と高值であっ た.さらに生検診断なしでも全例15点以上となり自己免 疫性肝炎を十分に疑うことが可能であった（表 2 ）。

考察

本邦での $\mathrm{AIH}$ の急性発症の頻度は $40 \%$ 前後と報告さ れており122)，我々の成績とも良く一致していた．臨床像 としては比較的若年の女性に多く, 自己免疫性疾患の合 併率が低く，劇症化例でなければ PSL に対する反応が 良好とされているが今回の症例も同様であった。特に PSL に対する反応は極めて良好で 2 例で中止できたことは與 味深かった. 一方で診断が遅れ劇症化した場合には予後 不良となる症例も報告されており ${ }^{2}$ ，迅速な診断が望まれ る. 今回の検討では国際診断基準 (1999年) ${ }^{3)}$ 用いれば 入院時でも十分に AIH を疑うことが可能であり，本基 準の有用性も示唆された。 
表 14 淀例の肝生検組織像

\begin{tabular}{|c|c|c|c|c|c|c|c|}
\hline & $\begin{array}{l}\text { bridging } \\
\text { necrosis }\end{array}$ & $\begin{array}{c}\text { piecemeal } \\
\text { necrosis }\end{array}$ & $\begin{array}{c}\text { focal } \\
\text { necrosis }\end{array}$ & $\begin{array}{c}\text { plasma cell } \\
\text { の浸澗 }\end{array}$ & rosette 形成 & $\begin{array}{c}\text { 中心静脈周囲の } \\
\text { 噮死 }\end{array}$ & $\begin{array}{l}\text { Kupffer cell } \\
\text { の反応 }\end{array}$ \\
\hline 症例(1) & $(-)$ & $(-)$ & $(+)$ & $(-)$ & $(-)$ & $(++)$ & $(+)$ \\
\hline 拝例(2) & $(+)$ & $(+++)$ & $(+++)$ & $(++)$ & $(-)$ & $( \pm)$ & $(+)$ \\
\hline 症例(3) & $( \pm)$ & $(+++)$ & $(+++)$ & $(+)$ & $(-)$ & $(++)$ & $(+++)$ \\
\hline 症例(4) & $(+)$ & $(+++)$ & $(+++)$ & $(++)$ & $( \pm)$ & $(++)$ & $(++)$ \\
\hline
\end{tabular}

症例(1のみプレドニソロン投与後の肝組織

表 24 症例の AIH 国膫猃断基蕉スコフ (1999)

\begin{tabular}{|c|c|c|c|c|}
\hline & 症例(1) & 症例(2) & 症例(3) & 症例(4) \\
\hline 性別 & 2 & 2 & 2 & 2 \\
\hline ALP/ALT, $y$-Glb & 4 & 4 & 3 & 4 \\
\hline 自己抗体 & 3 & 3 & 3 & 3 \\
\hline ウイルスマーカー & 3 & 3 & 3 & 3 \\
\hline 飲酒歴 & 2 & 2 & 2 & 2 \\
\hline 桼刘歷 & 1 & 1 & 1 & 1 \\
\hline 家族歴 & 0 & 0 & 1 & 0 \\
\hline HLA & 1 & 0 & 1 & 1 \\
\hline score 小計（生検診断前） & 16 & 15 & 16 & 16 \\
\hline 肝組織 & 0 & 4 & 3 & 4 \\
\hline 治療に对寸る反応 & 2 & 3 & 2 & 2 \\
\hline score 合計 & 18 & 22 & 21 & 22 \\
\hline
\end{tabular}

症例(1)のみプレドニソロン投与後の丹組織

しかしながら，急性発症例の中には国際診断基準の score の低い症例が多いとの報告4)5ももる. 今回は診断 確詥例のみでの検討のため score の低い症例は含まれて いない.scoreの高い症例には急性肝炎ではなく潜在的に 存在する慢性肝炎の急性增悪例が含まれるとの指摘もあ
るが，今回の組織学的検討ではそのような可能性のある 症例は 1 例（25\%）のみであった。一方で score の低い 症例の中には初期 $\mathrm{AIH}$ と鑑別困難な症例（薬郕性や AMA 陰性の原発性胆汁性肝硬変など）が含まれている 可能性もあり, scoreの低い症例での診断には慎重を要す るとともに症例の蓄積による急性発症例の診断基準の確 立も望まれる。

\section{結語}

AIH 急性発症例の 4 例を経験した. 臨床像は比較的特 徵的であり，早期診断・治療をおこなえば予後良好であ った.

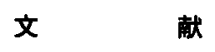

1) Omagari K, et al. : J Gastroenterol (1999) 34, 221.

2 ) 谷合麻紀子, 他：肝朠 (2000) 41, 517 .

3) Alvarez F, et al. : J Hepatol (1999) 31, 929.

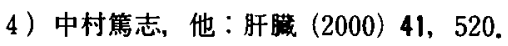

5) Abe M, et al : Hepatol Res (2001) 21, 213. 
岡山医学会雑誌 第114巻

August 2002, pp. $197-198$

\section{4 ）劇症肝炎及び急性肝炎重症型で発症した自己免疫性肝炎の臨床像}

長谷部 昌 ${ }^{1)}$, 阿部 雅則1), 熊木 天児1), 松原 寛 ${ }^{11}$

堀池 典生 ${ }^{1)}$, 恩地 森一 ${ }^{1)}$, 道克浩二郎 ${ }^{21}$, 二宮 常之 ${ }^{3)}$

キーワード：劇症肝炎, 急性肝炎重症型, 自己免疫性肝炎

\section{緒言}

自己免疫性肝炎 (以下 $\mathrm{AIH}$ ) の発症様式は一様ではな く急性肝炎あるいは劇症肝炎の経過をみる例が報告され ており，その予後は決して良くない，今回著者らは劇症 肝炎及び急性肝炎重症型で発症し, 治療に苦慮したAIH の3例を経験したので報告した。

症例 $1 ： 66$ 歳女性。2000年 4 月10日全身倦点感, 眼球 結膜黄染が出現. 近医に入院の上肝庇護剤による加療を 受けたが改善せず 4 月19日当科入院となった。 入院時 AIH スコアは16点であった(表)。パルス療法を含むステロイ ド療法を行ったが肝不全は改善せず，治療開始後40日目 にカンジ夕性肺炎, サイトメがロウイルス感染症を併発 し死亡した. 剖検肝は重量 $407 \mathrm{~g}$, 急性黄色肝萎縮の所見 であった。組織所見は著明なリンパ球浸潤と胆栓の形成 があり，広範な肝細胞の脱落壊死がみられた。

症例 $2: 53$ 歳, 女性。2000年11月初旬より発熱, 褐色 尿，全身倦急感が出現，12月13日当科入院となった。入 院時 AIH スコア16点であった (表)，ステロイドハルス 療法を施行し，GPT は低下したものの200〜300 IU/1 程度を推移。凝固能と黄疸は改善せず治療開始後約 3 ヶ 月の経過でカリ二肝炎を併発し死亡した。剖検組織所見 では著明なリンハ球浸潤と胆栓の形成があり，複小葉性 肝壊死の所見であった。

症例 3 : 50歳, 女性. 1999年 1 月17日に黄疸が出現. 同日近医入院し加療を受けたが改善しないため 1 月27日

指導：恩地森一（愛媛大学医学部第三内科）

1) 要姆大学医学部第三内汗

2) 爱媛大学医学部光学医療診療部

3) 愛媛県立中央病院内科

論文請求先：要湲大学医学部第三内科

電話：089-960-5820
当科転院となった. 入院時 $\mathrm{AIH}$ スコア15点であった(表). パルス療法を含むステロイド治療を行ったが, GPT は200 IU/ 1 程度までしか改善せず, 凝固能遅延, 黄㾝は改善し なかった，治療開始後 4 週を経過した時点で遅発性肝不 全への移行が照念され肝移植の適応と判断し 5 週後に生 体肝移植を行った，本症例では術前の感染症の併発はな く術後の経過も良好であった（図）。

\section{考察と結 語}

近年 AIH は增加傾向にあるが特に，組織学的に急性 肝炎像を呈して発症する症例が堌加している，当科にお ける48例の AIH 症例の組織学的検討によると13例（27 \%）が急性肝炎像を呈していた，13例中11例がステロイ ドにて治療され，そのうち 3 例 $(27 \%)$ がステロイド抵 抗性であった. . 今回報告した 3 例はいずれも急性発症し， いずれもステロイド抵抗性であった. 3 例中 2 例は劇症 化し感染症で死亡. 1 例は生体肝移植を施行し救命し得 た。死亡した 2 例は治療開始約 2 ケ月後に感染症を併発. 他の 1 例は 1 ケ月後に肝移植に踏みきり感染症を併発す

\begin{tabular}{|c|c|c|c|c|}
\hline & 例 & 1 & 2 & 3 \\
\hline T. Bil & $(\mathrm{mg} / \mathrm{dl})$ & 22.68 & 12.4 & 11.1 \\
\hline D. Bil & $(\mathrm{mg} / \mathrm{dl})$ & 17.97 & 10.8 & 7.1 \\
\hline GOT & (IU/ 1$)$ & 806 & 1,936 & 1,630 \\
\hline GPT & $(\mathrm{IU} / \mathrm{l})$ & 579 & 1,111 & 1,115 \\
\hline LDH & $(\mathrm{IU} / 1)$ & 326 & 1,384 & 728 \\
\hline ALP & $(I U / 1)$ & 896 & 592 & 268 \\
\hline LAP & $(\mathrm{IU} / \mathrm{l})$ & 99 & 95 & 118 \\
\hline$\gamma$-GTP & $(\mathrm{IU} / 1)$ & 52 & 185 & 92 \\
\hline $\mathrm{PT}$ & $(\%)$ & 50.6 & 53.7 & 35 \\
\hline IgG & (mg/dl) & 2,540 & 1.991 & 3,600 \\
\hline ANA & & $\times 640$ & $\times 1,280$ & $\times 160$ \\
\hline \multicolumn{2}{|c|}{ AIH score } & 16 & 16 & 15 \\
\hline
\end{tabular}




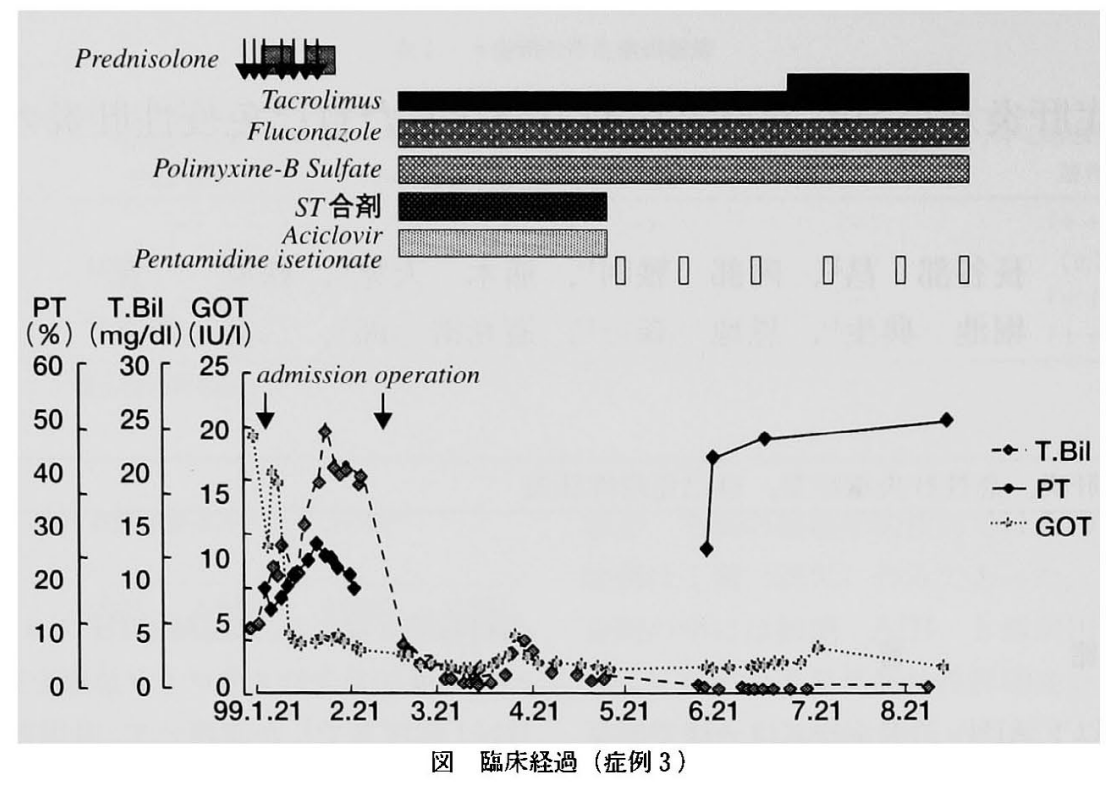

ることなく救命しえた，重症例に对しては早期の診断， 治療開始が重要である．特にステロイド抵抗例に对して は肝移植も視野に入れた治療方針の選択が重要であると 思われる.



1) Masanori Abe, et al. : Hepatology Research (2001) 23, 213-219. 
岡山医学会雑誌 第114巻

August 2002, pp. 199-200

\section{5 ）急性発症型自己免疫性肝炎の組織学的特徵}

$\begin{aligned} & \text { 岡野 信明, 山本 和秀, 坂口 } \text { 孝作, 三宅 } \text { 康広 } \\ & \text { 島田 典明, 箱田 知美, 鈴木 貴博, 寺田 亮 } \\ & \text { 馬場 伸介, 辻 孝夫 }\end{aligned}$

キーワード：急性発症型自己免疫性肝炎, 診断

\section{緒}

自己免疫性肝炎（以下 $\mathrm{AIH}$ ) は一般に中年以降の女性 に好発し，抗核抗体や抗平滑筋抗体などの自己抗体が陽 性で高ガンマグロブリン血症を特徵とする慢性に経過す る肝炎である。しかし，このような定型的な症例以外に， 原発性胆汁性肝硬変との overlap 症候群や急性肝炎様の 発症を示す非定型的な症例が存在する。そここで急性発症 型の AIH について組織学的特徴を検討した。

\section{対象と方法}

对象は平成 8 年から 13 年の間に当科で経験した急性肝 炎様の発症を示した AIH 9 症例である.ALT の最高值 は497-2161 (IU/1) で，うち 7 症例に黄疸を認めた。 抗核抗体陽性例は 7 例, 抗平滑筋抗体陽性例は 2 例で,

DR 4 または 2 は 8 例中 6 例に認めた。

肝組織像の評価には Ishak らの modified HAI score を用いた。 またホルマリン固定パラフィン切片を用い $\mathrm{CD} 4$ ， $\mathrm{CD} 8, \mathrm{CD} 79 \alpha$ に对するモノクロー十ル抗体で免疫染色 を行った。炎症細胞浸潤について, $\mathrm{CD} 4, \mathrm{CD} 8, \mathrm{CD} 79 \boldsymbol{\alpha}$ 陽性細胞を，portal，interface， lobularに分けて浸潤の 強さを評価した。

結果

modified HAI score の検討結果では, staging では $1-3$ の比較的早期の像を示寸症例が多く，Aから Dの

指導: 辻 辛夫

(岡山大学大学院医画学総合研究科 消化器 - 肝臟 - 感染症内科学) 論文請求先：岡山大学付属病院第一内科 電話：086-235-7219
各因子の中では, A因子の Interface hepatitis 及びB因 子の Confluent necrosis が強く認められた。

免疫組織学的検討のうち, 門脈域における浸潤細胞の 検討では, $\mathrm{CD} 8$ および $\mathrm{CD} 4$ 陽性 T細胞は, 非常に強い 細胞浸潤を認める症例や比較的強い浸潤を認める症例が 多く，また $\mathrm{CD} 79 \alpha$ 陽性 $\mathrm{B}$ 細胞も軽度浸潤から比較的強 い浸潤で認められた。

次に interface hepatitisにおける浸潤細胞の検討では， $\mathrm{CD} 8$ 陽性 T細胞が主体であったが, $\mathrm{CD} 79 \alpha$ 陽性 B 細胞 も比較的多く認められた.一方, $\mathrm{CD} 4$ 陽性 T細胞は少数 であった。

小葉内の浸潤細胞では CD 8 陽性 T細胞が主体であり， 一部に $\mathrm{CD} 4$ 陽性 $\mathrm{T}$ 細胞や $\mathrm{CD} 79 \alpha$ 陽性 $\mathrm{B}$ 細胞が認めら れた。

症例を提示する。症例は41歳，女性。主訴は全身僚䓌. 現病歴は, 生来健康であったが, H 9 年 5 月 10 日頃より, 全身供点, 皮膚搔痒感が出現し, 近医を受診, 肝障害を 指摘され入院した。安静のみで一時軽快したが，肝機能 の再上昇を認め，7月15日当科に紹介入院となった，入

\section{臨床経過}

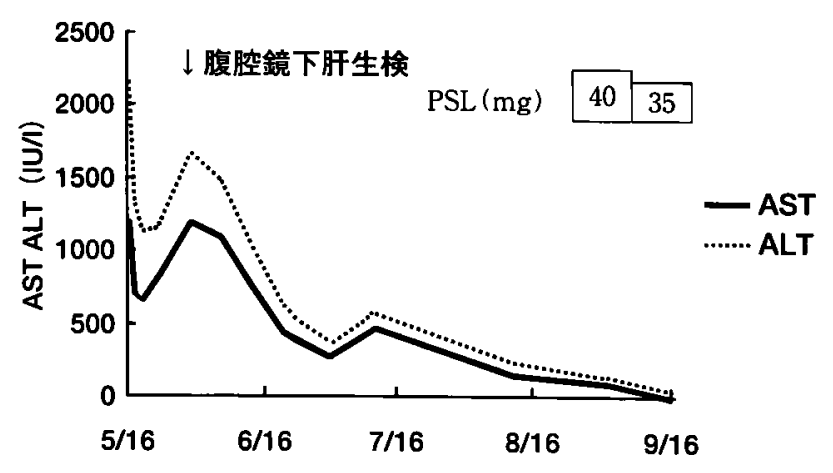

Fig. 1 症例（41歳女性）臨佅経過表 

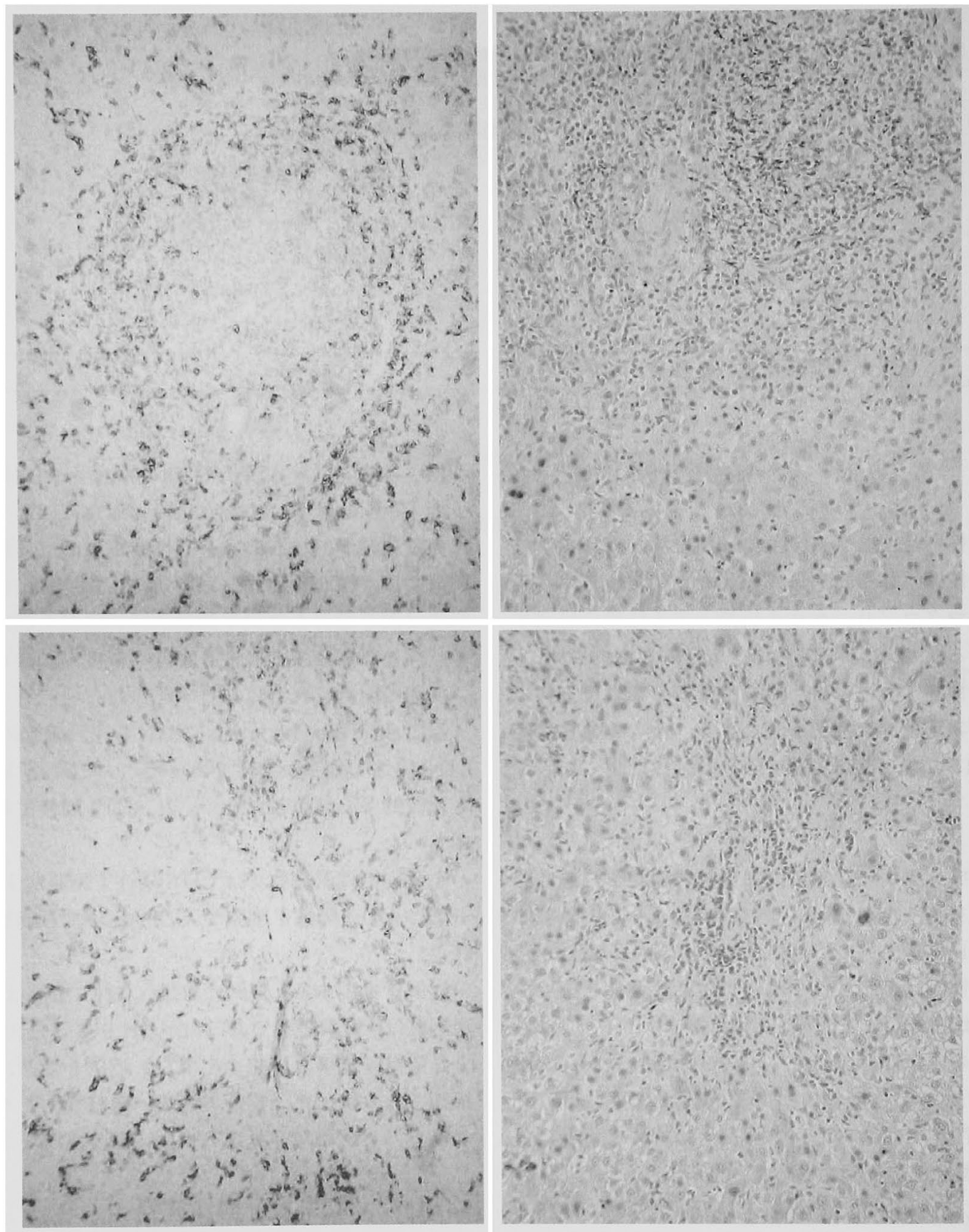

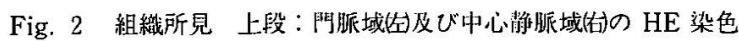
下段：門脈城因及び中心溯脈域伀)の CD 8 陽性 T細胞

院時検査成績では AST $592 \mathrm{IU} / 1$, ALT 929 IU/1, $\operatorname{IgG} 1724.2 \mathrm{mg} / \mathrm{dl}$, 各種ウイルス・マーカーは陰性で抗核 抗体が陽性, HLA は DR 2 及び DR 4 が陽性であった。 この症例の臨床経過を Figure 1 示す.トランス・ア ミナーゼは多峰性変動を示した. 二度目のピーク時に行 なわれた腹腔鏡下肝生検の組織を Figure 2 に示す。

HE 染色では, 強い interface hepatitis と中心静脈域
の zone 3 necrosis が認められた. 免疫組織学的には, $\mathrm{CD} 8$ 陽性 T 細胞が同部に一致して強く浸潤していた.

結

論

急性発症型 AIH では比較的発症早期の組織像を呈し, interface hepatitis と共に zone 3 necrosis が特徵的 であった. 同部に CD 8 陽性 T 細胞の浸潤を伴っていた。 
岡山医学会雑誌 第114巻

August 2002, pp. 201-202

\section{6) AIH-PBC overlap syndrome の 3 症例}

$\begin{array}{rrrr}\text { 秋澤 } & \text { 直明, 岩崎 } & \text { 信二, 前田 } & \text { 隆, 並川智香子 } \\ \text { 江川 } & \text { 徽, 高橋 } & \text { 昌也, 根本 } \\ & & \text { 禎久, 西原 利治 } \\ & & \text { 大西 三朗 } & \end{array}$

キーワード：AIH, PBC, overlap syndrome

\section{緒言}

以前より，原発性胆汁性肝硬変（Primary biliary cirrhosis : PBC) と自己免疫性肝炎 (Autoimmune hepatitis：AIH）の病態を同時性あるいは異時性に合わせ持っ た病態の存在が指摘されここれまでに PBC AIH mixed


报われてきた。あるいは，これらの病態は肝炎性の変化 の強い $\mathrm{PBC} の 1$ 垔系として取り扱われ，PBC hepatitic form とする報告もある ${ }^{3)}$.この PBC-AIH overlap syndrome においても，AIH あるいは PBC の病態に偏っ た症例があり，その治療法については一般的にはステロ イド剂が奏功することが多いとされているもののウルツ が有効なことも多く，その治療法は画一的ではない．今 回, 我々は当科で経験した PBC-AIH overlap syndrome の 3 症例について報告する.

症例 1 は48歳,女性. 1991年に全身倦㤐感と黄㾝を認 め当科入院. 入院時検查所見は, GOT $366 \mathrm{IU} / 1$, GPT $560 \mathrm{IL} / 1$, ALP $344 \mathrm{IU} / 1, \gamma$-GTP $222 \mathrm{IU} / 1, \mathrm{~T}-\mathrm{Bil}$ $3.2 \mathrm{mg} / \mathrm{dl}, \mathrm{ANF} \times 640, A M A \times 320$, IgG $1500 \mathrm{mg} / \mathrm{dl}, \mathrm{IgM}$ $335 \mathrm{mg} / \mathrm{dl}$, HLA DR 2 /DR 6 であった。肝生検にて，慢 性非化膿性破壊性胆管炎 (CNSDC) と高度の focal necrosis と piecemeal necrosis (PMN) を認めた. PBC

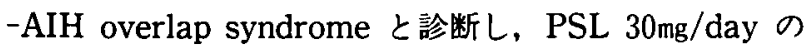
投与を開始したところ，GOT，GPT，胆道系酵素ともほ ほ正常值まで低下した. PSL 維持量 $30 \mathrm{mg} / \mathrm{day} て ゙$ GOT,

指導：大西三朗（高知医科大学第一内科）

詥文請求先: 高知医科大学第一内科

電話：088-880-2338
GPT は正常值を維持するも， $\gamma$-GTP は漸增した. 1994 年 1 月の肝生検で PMN は著明な改善を示したが CNSDC の改善を認めず (図 1)，その後も胆道系醭素が 漸增するため, UDCA $600 \mathrm{mg} /$ day の追加投与を開始した ところ改善を認め, 以後, $\gamma$-GTP の軽度上昇のみで経過 した. 1999年の肝生検では線維化と門脈域の炎症所見の 著明な改善を認めた。

症例 2 は57歳, 女性. 2000 年 4 月に全身倦点感と鼻出 血を主訴に近医入院. 入院時検查所見は, GOT 590 IU/ 1, GPT 447IL/1, ALP 445IU/1， $\gamma$-GTP 222 $\mathrm{IU} / 1$, Platelet $8.8 \times 10^{4} / \mu \mathrm{l}, \mathrm{ANF} \times 80, \mathrm{AMA} \times 80$, IgG $3690 \mathrm{mg} / \mathrm{dl}$, IgM $429 \mathrm{mg} / \mathrm{dl}$, HLA DR 4 /DR 9 であ った. PBC と診断され，UDCA $900 \mathrm{mg} /$ day と SNMC の投与を開始. 胆道系醭素は正常化するも，GOT，GPT 異常，血小板減少が持続するため精查加療目的で当院転 院. 転院後に施行した肝生検では明らかな胆管病変を認 めず, chronic active hepatitis（A 2/F 3) の所見を認 めたため, PSL 30mg/day の追加投与を開始したところ， GOT, GPT, 血小板数とも速やかに改善した. 以後, PSL 漸減し, PSL $5 \mathrm{mg} /$ day, UDCA 600mg/day にて再燃を 認めていない. 尚, 血小板減少は ITPの合併であった. 症例 3 は68歳, 女性. 1992年頃より軽度の肝機能異常 あり。1999年 6 月に近医で，GOT 5891U/1，GPT 453 IL/1，ALP 367IU/1 と肝機能異常を指摘され当科に紹 介入院となった。入院時検查所見では, $\mathrm{ANF} \times 320$, $A M A \times 80$, IgG $2320 \mathrm{mg} / \mathrm{dl}$, IgM $680 \mathrm{mg} / \mathrm{dl}$, HLA DR $4 /$ DR 8 であった。肝生検では CNSDC と高度の線維化, bridging necrosis (A 3 / F 3 )を認めた. UDCA 600m/ day の投与を開始するも効果を認めず, PSL $30 \mathrm{mg} /$ day の 追加投与にて肝胆道系酵素は正常化した. 以後, PSL 漸 減し, PSL $5 \mathrm{mg} / \mathrm{day}$, UDCA $600 \mathrm{mg} / \mathrm{day} に$ に再燃を認 



区 1 PSL 投与前後での肝組織像の比較（症例 1）

めていない

\section{考察と結論}

症例 1 ではステロイド剂と UDCA を STEP BY STEP に投与し治療を行った，ステロイド剂により $\mathrm{AIH}$ の病 態が消失した後，PBCの病態が顕性化したと考えられ， UDCA を追加併用することで改善した.

症例 2 は典型的 CNSDC を認めず, 肝細胞障害が主病 変であったことから, 病態としては AIH 寄りの overlap syndrome と考えられた. 胆道系酵素異常に对しては UDCA が奏功したが, AIH の病態の肝細胞障害に対し てはステロイド剂の投与を必要とした。自己免疫性肝疾 患のITP 合併の報告例は少なく, 我々が検索し得た範囲
では, AIH での合併例が散見される程度であり, overlap syndrome 例での合併例は他に報告を検索し得なかった。 症例 3 は CNSDC を認めるものの肝細胞障害が高度で あり，病態としては AIH 寄りの overlap syndrome と 考えられた。治療としては, UDCA では効果がそしく, やはりステロイド剤が奏功した。

以上，overlap syndrome の治療に際しては，その病 態に応じた柔軟な対応が必要であると考えられた。

\section{文献}

1) Berg, et al : Lancet (1980) 2, 1329-1332.

2) Popper H, et al : In : Progress in liver disease Vol. III (1970), 336-354.

3 ) Lohse AW, et al : Hepatology (1999) 29, 1078-1084. 


\section{7 ）高齢発症自己免疫性肝炎の臨床的検討}

石川剛

キーワード：自己免疫性肝炎, 高齢者, 合併症

緒言

自己免疫性肝炎（以下 AIH）の年齢分布について，欧 米においては若年者及び中年以降の二峰性であることが 知られているが，本邦では中年以降にそのピークがある とされている。我々は当科で経験した AIH 44例のうち 70 歳以上で診断された 9 症例を対象に臨床的検討を行っ た.

\section{対 象}

70 歳以上で診断された AIH 患者 9 症例を対象とし, その平均年齢は73.5歳で全例女性であった．黄疽を主訴 に入院したのが 3 例 (33\%)，胃静脈瘤破裂が 1 例(11\%)， 肝障害精查目的が 5 例（56\%）であった。

\section{結果}

各症例の詳細に関しては表 1 に示した通りである.AIH の亜型分類では type I が 8 例 (89\%)，type IVが 1 例 （11\%）で，診断時の病理組織像は Liver cirrhosis（以 下 LC) が 4 例 (44\%), Chronic active hepatitis（以下 CAH）（2 B)が 5 例 (56\%)であった．また HLA typing が検索できた 6 例のうち DR 4 陽性が 5 例 (83\%)，DR 2 陽性が 1 例（17\%）であった。 なお AIH の診断基準 (scoring system) による治療前の評価は全ての症例に おいて“確診”であった，合併症は異時性肝細胞癌：1 例, 胆囊癌： 1 例, 早期胃癌： 2 例, 糖尿病：2 例, 高 血圧症：3 例, 橋本氏病：1 例, 多発性巨大肝輁胞：1 例, 帯状疮疹：1例であり，9例中 4 例 $(44 \%)$ に発癌 が認められた。

指導：児玉隆浩（山口県立中央病院消化器科）

論文請求先：山口県立中央病院消化器科

電話：0835-22-4411
AIH はその肝細胞障害に自己免疫機序の関与が推定さ れている慢性活動性肝炎である。日本では中年女性に発 症することが多くその発症年齢は50歳代をピークとして いるが，最近ではさらに高齢化の傾向にある．また欧米 では AIH の約半数が30歳以下で，中年以降の発症とあ わせて二峰性を呈しており，若年で発症する症例と中高 年で発症する症例ではその免疫遺伝学的背景が異なるこ とが予想されている゙．当科で経験した AIH 44例（男性 4 例，女性40例）の発症年齢の分布はグラフ1に示した 通りで，50～60歳代が26例と全体の59\%を占めており， 70 歳以上での発症も 9 例（20\%）に認如れた．今回対 象とした高齢発症 AIH 9 例の診断時の病理組織像は LC が 4 例 (44\%)，CAH（2 B）が5例（56\%）であった が，岡らの報告”による全年齢を対象とした AIH の病理 組織像（慢性活動性肝炎：72\%, 慢性非活動性肝炎：2 $\%$ ，肝硬変：20\%，その他：7\%）に比べると進行例が 多く若年〜中年発症例上り予後不良であるといえる た70歳以上で診断された 9 症例の合併症は前述の如くで あり，9例中 4 例 $(44 \%)$ に発癌が認められたことに注 目しなければならない，なお当科において70歳未満で診 断された AIH 35例のうち発癌症例は肝細胞癌：2 例, 胆管癌：1 例, 卵巣癌：1例の計 4 例 $(11.4 \%)$ であり, 高龄（70歳以上）発症患者の癌合併率が若〜中年（70歳 末満) 発症例の3.9倍にも及んでいることは特筆すべき事 実である. 従って通常の高齢者と同様, AIH 症例におい ても加秢と共に発癌率が增すことを念頭に置きながら， 肝葴のみに捉われることなく厳重なる全身検索を行うこ とが必要だと考える。 
表 1 高齢発症 AIH 9 症例

\begin{tabular}{|c|c|c|c|c|c|c|c|c|c|c|c|c|}
\hline Name & $\begin{array}{c}\text { Age } \\
(y .0)\end{array}$ & Type & Histology & HLA & Score & $\begin{array}{c}\text { T. B } \\
(\mathrm{mg} / \mathrm{dl})\end{array}$ & $\begin{array}{c}\text { AST } \\
(\mathrm{IU} / 1)\end{array}$ & $\begin{array}{c}\text { ALT } \\
(\mathrm{IU} / 1)\end{array}$ & $\begin{array}{l}\gamma \text {-Glob } \\
(\mathrm{g} / \mathrm{dl})\end{array}$ & $\begin{array}{c}\mathrm{IgG} \\
(\mathrm{mg} / \mathrm{dl})\end{array}$ & $\begin{array}{c}\text { ICG (R15) } \\
(\%)\end{array}$ & Complication \\
\hline G. M & 75 & I & LC & $\mathrm{DR} 4$ & 19 & 1.2 & 77 & 53 & 1.95 & 2,360 & 23 & Herpes zoster, DM \\
\hline N. U & 78 & I & $\mathrm{CAH}(2 \mathrm{~B})$ & $\mathrm{DR} 4$ & 21 & 12.4 & 1,302 & 704 & 2.6 & 3,431 & 19 & $(-)$ \\
\hline T. S & 75 & I & $\mathrm{CAH}(2 \mathrm{~B})$ & $\mathrm{DR} 4$ & 21 & 0.9 & 96 & 52 & 2.2 & 3,564 & 19 & Early gastric cancer (IIa) \\
\hline Y. T & 78 & I & $\mathrm{LC}$ & DR4 & 17 & 1.3 & 66 & 48 & 0.97 & 1,478 & 17.7 & Early gastric cancer (IIc) \\
\hline N. K & 70 & I & $\mathrm{CAH}(2 \mathrm{~B})$ & DR2 & 16 & 41.2 & 359 & 296 & 1.75 & 2,470 & $(-)$ & Hypertension, Angina pectoris \\
\hline M. E & 71 & I & LC & $(-)$ & 19 & 1.0 & 24 & 10 & 2.16 & 2,723 & 37.5 & Hashimoto's disease, DM \\
\hline T. T & 71 & I & $\mathrm{CAH}(2 \mathrm{~B})$ & $(-)$ & 18 & 0.7 & 92 & 68 & 2.48 & 2,810 & 15.1 & GB cancer, Hypertension \\
\hline I. $\mathrm{S}$ & 72 & N & LC & DR4 & 18 & 1.5 & 149 & 79 & 2.8 & 4,094 & 42.5 & HCC, Hypertension \\
\hline S. S & 72 & I & $\mathrm{CAH}(2 \mathrm{~B})$ & $(-)$ & 19 & 7.2 & 1,328 & 993 & 2.27 & 2,700 & 37.5 & Multiple giant liver cysts \\
\hline
\end{tabular}

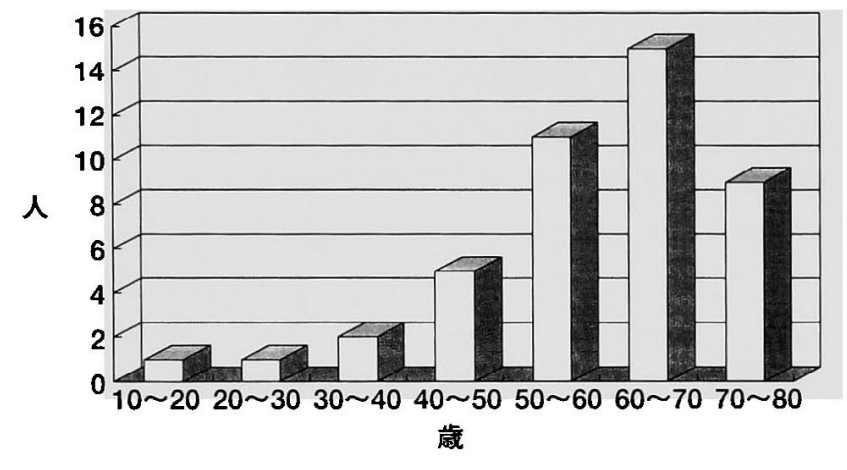

図 1 発症年路の分布

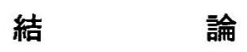

高齢発症 AIH では診断時すでに組織学的進行例が多
く，さらに肝臓のみならず他臓器も含めて発癌頻度が高 いため，それらは生命予後に大きな影響を及ぼすといえ る. 現在進みつつある高齢化社会のなかで AIH という 一疾患だけに目を向けることなく，より広い視野をもっ て診療に当たらなければならない。

\section{文献}

1) 戸田剛太郎, 他: 自己免疫性肝疾患, 文光堂, p 76- p 127 .

2) 岡博, 他：自己免疫性肝炎：全国調查. 厚生省特定疾患“難 治性肝炎”調查研究班, 自己免疫性肝炎分化会。昭和63年度報 告書1989, $\mathrm{p} 237-\mathrm{p} 241$.

3) 東條淳, 他：当科に扮ける自己免疫性肝炎76例の予後に関寸 る検討, 肝藏 41 ( 7 ), p 52- p 54.

4 ) 戸田剛太郎, 他：自己免疫性肝炎をめぐる最近の話題, 肝胆脺 $43(1), \quad$ p $9-$ p 99 . 
岡山医学会雑誌 第114巻

August 2002, pp. 205-206

\title{
8 ）高度の黄疸を伴った高齢者の AIH の 1 例
}

\author{
山本晋一郎, 武居 道彦, 國枝 武美, 柴田 憲邦
}

キーワード：自己免疫性肝炎, 黄㾝, ビリルビン吸着

\section{緒言}

自己免疫性肝炎 (autoimmune hepatitis； AIH) の症 状として, 黄㾝は30４0\%の頻度で認められるといわれ, また劇症化し肝不全で死亡する例乎報告されている。 回, 高度の黄疸が遷延し重症化を認妉高齢者の AIH の 1 例を経験した．遷延する黄疸に对して，ビリルビン吸 着とステロイド投与により寛解したので，その臨床経過 を報告する。

\section{症例}

76 歳，女性. 平成 4 年 4 月， 9 月，平成 5 年 9 月と過 去 3 回黄疸を伴う GPT の上昇を認め保存的治療で軽快 した。平成10年 8 月末に黄㾝が出現し 9 月 24 日にはビリ ルビン $36 \mathrm{mg} / \mathrm{dl}$ (直接型 $90 \%$ ), GOT $671 \mathrm{IU} / \mathrm{L}$, GPT 573 $\mathrm{IU} / \mathrm{L}$ と高度の黄疸を認め, 入院した. 入院時検查成績で は, 白血球 $2900, \mathrm{Hb} 11.1 \mathrm{~g} / \mathrm{dl}$, 血小板23.6万, ALP 427 IU/L, $\gamma$ GTP $75 \mathrm{IU} / \mathrm{L}$, PT $69.8 \%$, HPT $58.4 \%$, $\mathrm{HBsAg}(-), \mathrm{HCV}$ 抗体(一)であった. また抗核抗体 (一) であったが抗平滑筋抗体 $320 \times$, IgG $1770 \mathrm{mg} / \mathrm{dl}, \mathrm{HLA}$ DR 4，8であった. AIH 基準”で19点（表1）となり， 確診所見であった.

\section{入院後経過（図 1$)$}

高度の黄㾝が持続するため，9月30日よりプレドニソ ロン $30 \mathrm{mg} /$ 日の経口投与を開始した. しかしビリルビンは 遷延するため，10月 8 日より 3 日間，ビリルビン吸着用 カラム（クラレ KM 8800）を用いてビリルビン吸着を施

指導 : 山本晋一郎 (川崎医科大学内科学消化器 1 部門)

論文請求先：川崎医科大学内科学消化器 1 部門

電話：086-462-1111 FAX：086-462-1199
行した。その後, 血清ビリルビンは低下し，12月７日には $3.2 \mathrm{mg} / \mathrm{dl}$ （直接型 $44 \%$ ）となったため退院した。なお本 症例は平成 4 年上り自己免疫性溶血性實血と診断されて おり,間接型優位のビリルビン上昇は現在も続いている. また11月30日に行った肝生検では, 門脈域の軽度の纎維 化，リンハ球浸潤があり，肝小葉内にはリンハ球浸潤と 単細胞壊死があり， $F_{1} / A_{1}$ (新犬山分類) と判定された。

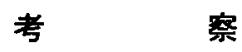

$\mathrm{AIH}$ は近年わが国でもしばしば報告され，40歳以降の 女性に好発することはよく知られている．今回報告した 症例は76歳という高齢で, 平成 4 年以来急性発症を 3 回 繰り返している。平成 6 年以降は急性発症がみられない 時期があったが, 4 年後の平成 10 年にビリルビンが $30 \mathrm{mg} / \mathrm{dl}$ を越之る高度の黄疸を伴った急性発症がみられた。 $\mathrm{AIH}$ の重症型は鈴木らによれば本邦で31例あり，うち8 例は 劇症化を示し，予後は極めて悪い．また2001年に厚生省 の研究班のまとめ)では，AIH によるものは劇症肝炎68 例中 1 例, 亜急性型60例中 9 例を占めていると報告され ている．今回の症例は劇症肝炎には当てはまらないが, 極めて高度の胆汁うっ滞を伴った AIH 例で，ビリルビ ン吸着療法とステロイドが極めて奏効し寛解を認めた点 が特徵的であった。



76歳，女性で高度の黄㾝を呈した自己免疫性肝炎の 1 例を呈示した．本例はビリルビン吸着とステロイド投与 が奏効した。

丢 考 文 献

1) Aliborez, et al. : J Hepatol (1999) 31, 929-938.

2 ）鈴木智浩, 他：肝臓 (1999） 40，135-140.

3 ）坂井田功, 他：侜胆兴 (2001) 43，85-90. 
山本晋一郎：他 3 名

\section{表 1 自己免疫性肝炎診断基染}

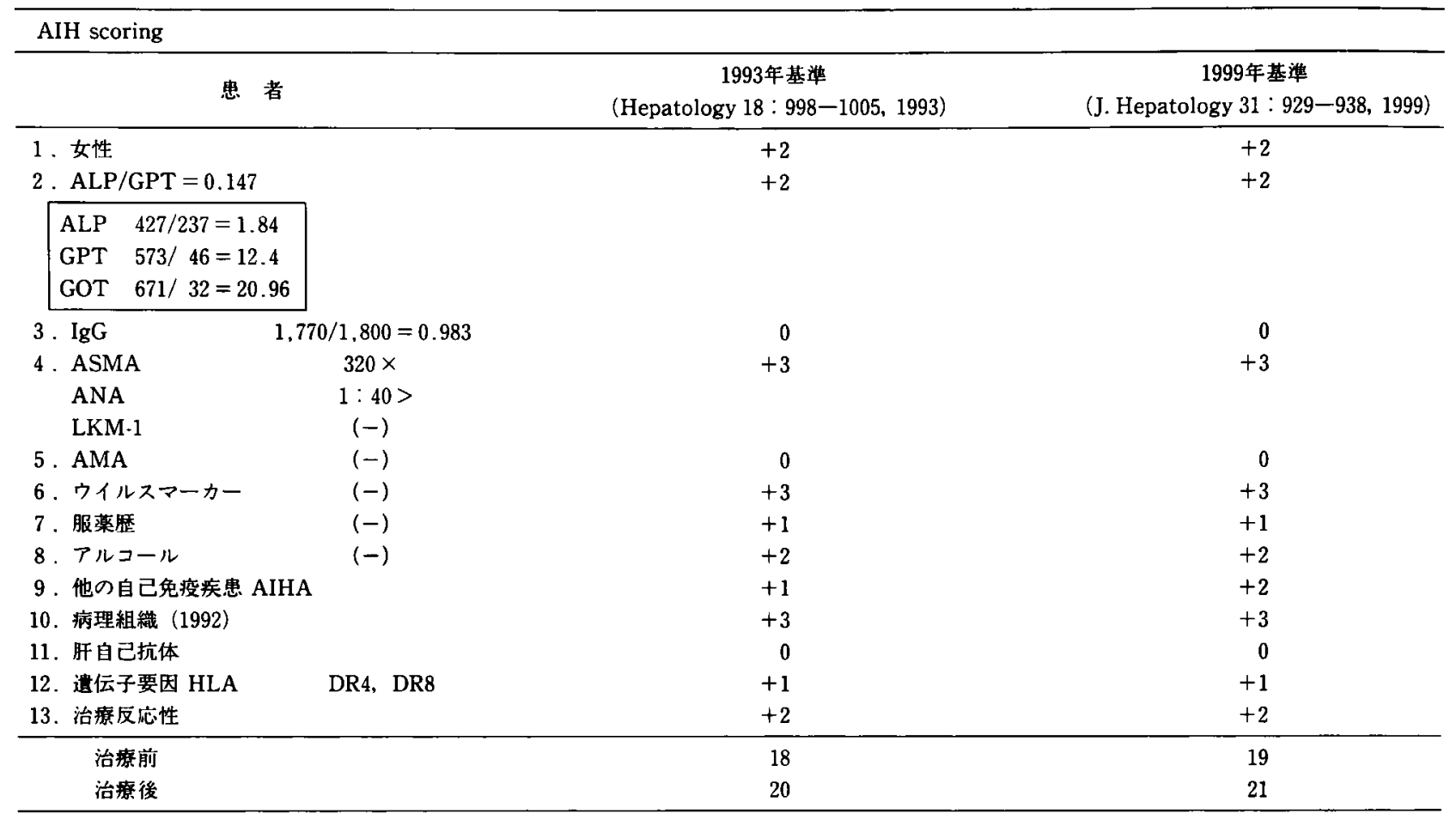

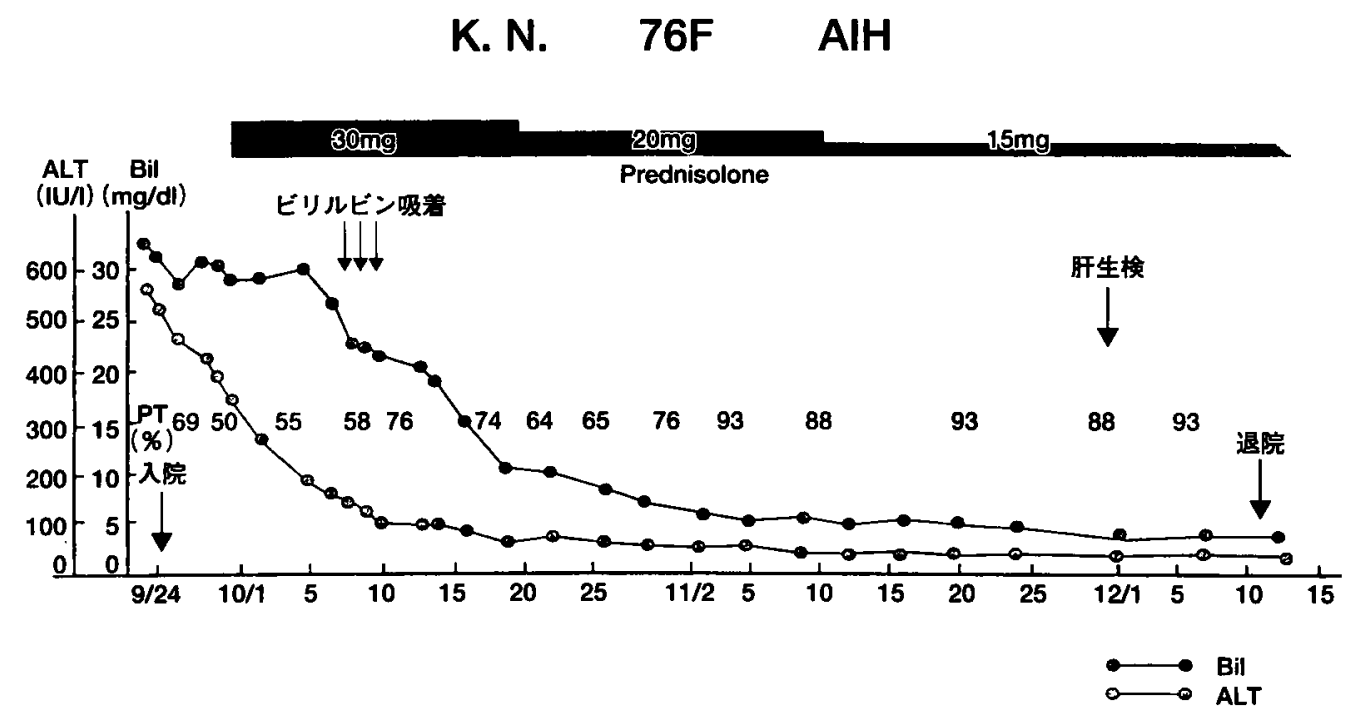

図 1 入院後の臨床経過 


\title{
9 ）自己免疫性肝炎が疑われた一男児例
}

\author{
飯塚 俊之 ${ }^{1)}$, 村上 潤 ${ }^{1)}$, 岡本 学 ${ }^{1)}$, 長田 郁夫 ${ }^{1)}$ \\ 田澤 雄作 ${ }^{2)}$, 白木 和夫 ${ }^{3)}$
}

キーワード：ミノマイシン, 自己免疫性肝炎, 薬剤性肝炎

ミノマイシン（MINO）内服後に重症急性肝炎を呈し た自己免疫性肝炎疑詥例を報告する。

\section{症例}

症 例：10歳, 男児.

主 訴：黄疸。

家族歴，既往歴：特記すべきことなし.

現病歴：平成11年12月から平成12年 3 月末までに近医 で感冒様症状に対して MINO を $100 \mathrm{mg} /$ 日延べ33日間処 方されていた. 2000 年 4 月に全身供怠感のため MINO 内 服を中止したが，その後黄㾝出現したため，同年 5 月 8 日某病院小肾科入院した。 T. Bil $8.7 \mathrm{mg} / \mathrm{dl} ，$ D. Bil 5.8 $\mathrm{mg} / \mathrm{dl}$, AST $1663 \mathrm{IU} / 1$, ALT $1380 \mathrm{IU} / 1, \gamma$-GTP 54 $\mathrm{IU} / 1, \mathrm{ChE} 157 \mathrm{IU} / 1, \operatorname{Alb} 4.0 \mathrm{~g} / \mathrm{dl}$, プロトロンビン 時間 (PT) $85 \%$ であった. 強力ミノファーゲンC (SNMC) 投与し， $60 \mathrm{ml} /$ 日まで增量したが，黄疸の悪化と PT 延 長が認められたため, 精查加療目的で同年 6 月 6 日当科 紹介転院した。

入院時現症：意識清明，皮虑に黄㾝あり。腹部平担で 腹水を認めず, 肋骨弓下に肝蔵を $2 \mathrm{~cm}$ 解知, 脾臓は不触 知であった，腹壁静脈怒張なく，手掌紅斑もなかった。

入院時検查所見：T. Bil 17.6mg/dl, D. Bil $11.9 \mathrm{mg} / \mathrm{dl}$, AST $1600 \mathrm{IU} / 1$, ALT $648 \mathrm{IU} / 1$, ALP $697 \mathrm{IU} / 1, \gamma$ -GTP $80 \mathrm{IU} / 1$, ChE $61 \mathrm{IU} / 1$, Alb $2.9 \mathrm{~g} / \mathrm{dl}$, ammonia $74 \mu \mathrm{g} / \mathrm{dl}$, PT $60 \%$, IgG $1210 \mathrm{mg} / \mathrm{dl}$, HBs 抗原 $(-)$, HBc

指導: 長田郁夫 (鳥取大学医学部小児科)

1) 鳥取大学医学部小児科

2）町立大河原病院小児科

3) 聖路加看護大学

椧文請求先：鳥取大学医学部小児科

電話：0959-34-8109
抗体 (-), HCV 抗体 (-), 抗核抗体160倍, 抗ミトコン ドリア抗体 $(-)$ ，抗平滑筋抗体 $(-)$, 抗 LKM 1 抗体 (一)，セルロプラスミン $30 \mathrm{mg} / \mathrm{dl}$ であった. 肝針生検では 重症急性肝炎の像で，一部に亜広範性壊死を認めた。

入院後の経過（図 1）：MINOに上る薬㘊性肝炎と考 えて，プレドニン (PSL) $30 \mathrm{mg} /$ 日内服を開始した。黄疸 の消失とトランスアミナーゼ值の正常化が認められ, 内 服 4 力月で PSL を漸減・中止した. 中止後 6 力月で卜 ランスアミナーゼ值が再度上昇したため, 当科に再入院 した. 2 回目の肝生検では慢性活動性肝炎であり，自己 免疫性肝炎の再燃（疑診例）と診断した.PSL 治療を再 開し、トランスアミナーゼ值の正常化が再度確認された。

\section{考察及び結語}

Elkayam は MINOにより誘導された自己免疫性肝炎 30 例を検討し，男に多く，MINO 投与期間も 2 力月～ 120 力月に渡 り，抗核抗体陽性率 $89 \%$ と高率で, MINO 内服 の中止により多くの症例では 3 力月以内にトランスアミ ナーゼ值が正常化するが，副腎皮質ステロイド投与を必 要とする症例もあったと報告している。․․ MINO 内服後 に抗核抗体陽性の重症急性肝炎を呈した本症例は，当初 自己免疫性肝炎の診断基準を満たさなかった，MINOに よる薬剤性肝炎と考之て行ったステロイド療法は著効し たが，内服中止 6 力月後に再燃した，再燃後のステロイ ド再投与にも著効を示しており，自己免疫性肝炎の疑診 例と診断し得た。

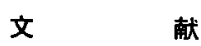

1) Ori Elkayam: Seminars in Arthritis and Rheumatism (1999) 28, 392. 


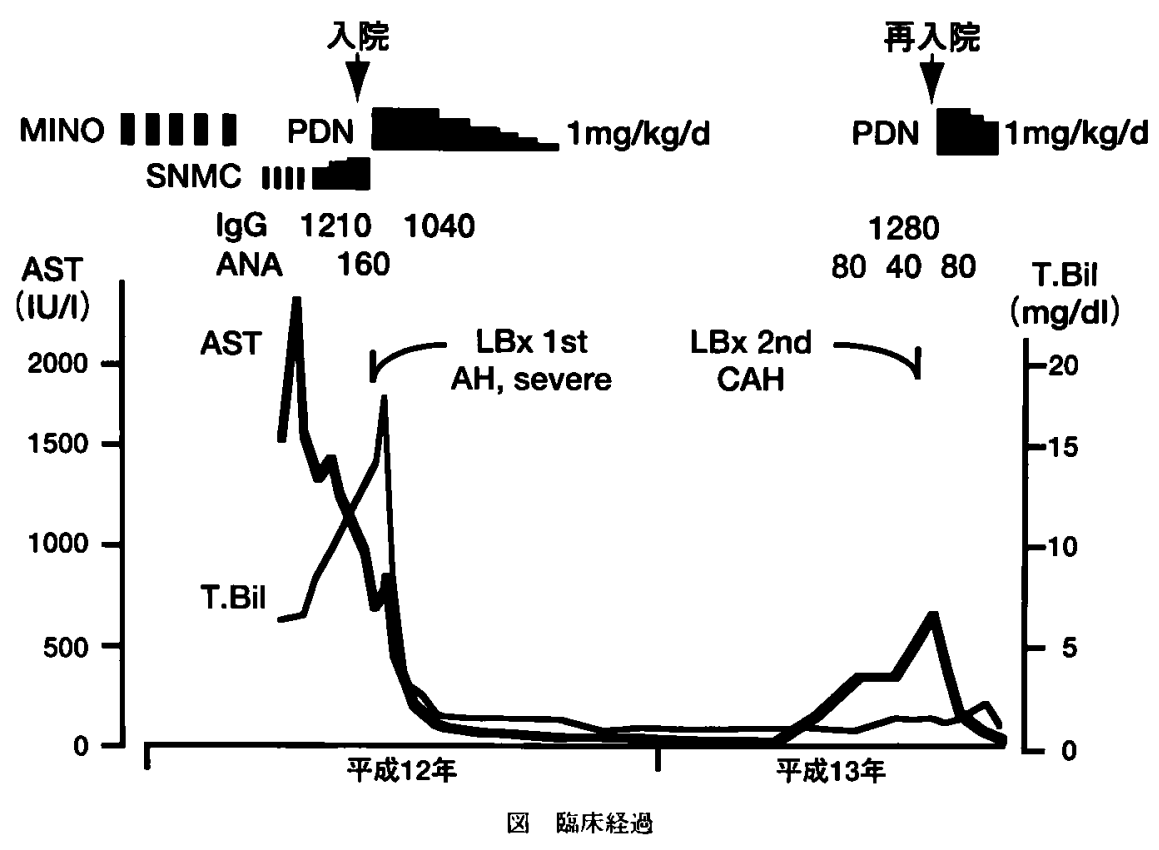




\section{0）自己免疫性肝炎とその周辺疾患における診断と治療法の選択の問題点}

是永 匡紹，日野 啓輔，原裕一，北瀬彰

佐藤 康弘, 任粉 玉, 藤原 大輔, 奥田 道有

沖田極

キーワード：自己免疫性肝炎, scoring system

\section{緒言}

1993年に自己免疫性肝炎（以下AIH）の診断基準であ る scoring system が提案され，診断の普遍化がなされ， 1999年の改訂により，自己抗体陽性薬剂性肝炎や胆道疾 患を積極的に除外しようとしているが，依然として scoring system だけでは鑑別できない境界病変や非典型例が存在 し, 診断や治療法の選択に苦慮する症例も少なからず経 龭する。



対象は，過去 6 年間で，自己抗体陽性·lgG， $\gamma$-globlin 高值・ウイルスマーカー陰性・黄㾝の 4 項目のうち， 2 項目を有する原因不明の肝障害のため AIH が疑われ, 当科に紹介入院し肝生検が施行された 45 症例（男 6 名. 女39名）で、これらを，新しい scoring system に基づ いて再検討し，その治療法選択の妥当性について検討した。

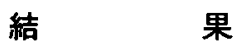

definite AIH は16例（36\%）であり, probable AIH は19例(42\%)であった. AMA 除性 PBC ゃ AIH - PBC overlap と考之られた症例（7例）は, score が 9 点以下 であった， HCV 陽性は，6例でprobable $\mathrm{AIH} に 3$ 例 含まれた。

definite AIH 16例は, 全例女性, type 1 AIH であ $\eta ， 16$ 症例中13例で，ステロイドが投与され著効した。

指導：沖田 極（山口大学医学部第一内科）

諭文請求先：山口県宇部市南小串 1-1-1

電話：0836-22-2572
他の 3 症例は， 2 例が合併症の為ステロイドが投与でき ず，残りの1例では，経過中肝機能が正常化し， patient の希望もあっため drug free で経過観察したが，以後 3 年間肝機能は，持続正常である。

probable AIH 19例では, definite AIH に比べて男性 例（5例）やdrug 内服歴（9例）を有する症例が多く含 まれており, Score 13点以上で腹臆鏡や肝組織で広範壊 死を認める症例や，DR 3，4 陽性例には，ステロイドが 投与され (13例)，HCV 陽性の 1 症例を除き著効した。 一方, UDCA 投与の選択は, score が低く, 経過中肝機 能が落ち着きつつある症例が対象で，観察期間内では， 再燃を認めなかった。

投薬せずに経過観察した 2 症例のうち初回発症時 score が10点であった 1 例は肝機能正常化せず，半年後自己抗 体が初めて陽性化した。このためステロイドを投与し， 著効した為，この時点で definite $\mathrm{AIH}$ の診断が可能に なった

$\mathrm{HCV}$ 陽性者 6 例中, probable AIH と診断される症 例が 3 例認められ，1例はステロイド投与により增悪した。

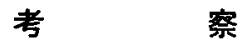

definite AIH では，ステロイド投与が first choice と 考えられた，probable AIH においては，特に肝組織や 腹腔鏡の所見が重要と考之られ, severe な肝障害や score が13点以上の症例にはステロイド投与が有効であった。 一方組織の炎症が低い症例やDR3，4陰性例では，UDCA 投与や経過観察を行い, 肝炎の增悪が出現したあと、ス テロイド投与を行ってもよいのではないかと考えられた. 男性例，薬剂内服例・HCV 陽性例は，低めに算定される ため, 診断を決めつけずに、積極的な肝生検や経過観察 が必要であると考えられた ${ }^{1-4)}$. 
文

献

1) Alvarez F, et al. : J Hepatol (1999) 31, 929.
2 ）渡辺文時, 他：肝䑏（1997）38，646.

3 ) 戸田剛太郎：肝臟 (2000) 41，151.

4) 中沼安二, 他：肝胆脺 (2001) 43(1)，35. 


\title{
第18回 中・四国肝臓病研究会
}

\author{
期 間：平成13年 9 月 8 日 \\ 会 場：岡山プラザホテル 4 階 \\ 碩 問：平山千里, 伊藤憲一, 島田宜浩, 山本泰猛 \\ 白木和夫, 西岡幹夫, 川崎寛中, 梶山梧朗 \\ 世話人：辻 孝夫, 沖田 極, 伊東 進, 恩地森一 \\ 大西三朗, 山本晋一郎, 茶山一彰 \\ (平成14年 6 月 14 日受稿)
}

\section{主 題 $\quad \mathrm{B} \cdot \mathrm{C}$ 型肝炎の臨床的差異}

\author{
司 会：沖田 極（山口大学医学部第一内科教授） \\ 山本晋一郎（川崎医科大学内科消化器 1 教授）
}

\section{1 ）無症候性 C 型肝炎ウイルス持続陽性者の臨床的特徴： 無症候性 B 型肝炎感染者との比較検討}

\author{
孝田 雅彦, 岡本 欣也, 三村 憲一, 村脇 義和 \\ 川崎 寛中
}

キーワード：無症候性 C 型肝炎ウイルス感染者, 無症候性 B 型肝炎感染者, 膠質反応

緒

$\mathrm{C}$ 型肝炎ウイルス $(\mathrm{HCV})$ 感染の診断が可能となって 以来, $\mathrm{B}$ 型と $\mathrm{C}$ 型慢性肝疾患の臨床病理学的違いが明ら かになってきている，きらに，B型肝焱ウイルス $(\mathrm{HBV})$ 感染と同様, HCV 感染者のうち約 $30 \%$ 程度に血清卜ラン スアミナーゼが持続して正常な無症候性 HCV 感染者が 存在することがかかってきだ，今回，無症候性 HCV 感 染者の臨床的特徴を明らかにするために無症候性 HBV 感 染者と臨床検查值を比較検討しました。

指复：村勝義和（鳥取大学医学部第二内科）

論文蘢求先：鳥取県米子市西町 36- 1

電話：0859-33-1111
対象・方法

無症候性 $\mathrm{HBV}, \mathrm{HCV}$ 感染者の定義は(1)HBs 抗原陽 性あるいは HCV-RNA 陽性 (2)観察期間中常に血清 ALT，AST が正常範囲内 (3)慢性肝疾患の臨床所見を 認めないものとしました。無症候性 HBV 感染者22例(男 性 7 例, 女性15例；平均年齢 $47 \pm 13$ 歳, e 抗原陽性 5 例, e 抗体陽性17例) 無症候性 HCV 感染者27例（男性 7 例, 女性20例：平均年齢66士14歳，セロタイプグループI： 16例，グループ II； 7 例，判定不能； 4 例) コントロー ルとして正常健常者26例（男性 9 例，女性17例，平均年 齢60土10歳)で検討した。無症候性 HBV 感染者のうち, 14例が検診で 5 例が献血時検査で， 3 例が術前検査で発 見された。無症候性 HCV 感染者のうち19例が検診で 5 例が入院時検查で 3 例が内視鏡検查で発見された. HBV



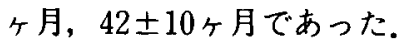




\section{結果}

無症候性 HBV, HCV 感染者で血清ビリルビン, ALP, AST, ALT, GGT, コレステロール, ChE, アルブミン は正常範囲内にあり両者間で差は認めず，健常者とも差 を認めなかった（表 1)。これに対して無症候性 HCV 感 染者では血清 TTT，ZTT， $\gamma$-globulin，IgG が上㫒し 健常者, 無症候性 HBV 感染者に比べて明らかに上昇し ていた．血清 TTT, ZTT, $\gamma$-globulin, IgG の異常率 は無症候性 HCV 感染者でそれぞれ $89 \% ， 89 \% ， 37 \%$, $37 \% に$ 対して, 無症候性 HBV 感染者ではそれぞれ $23 \%$, $27 \%, 9 \%, 5 \%$ あっった。血清 TTT, ZTTは $\gamma$-globulin とそれぞれ $\mathrm{r}=0.645, \mathrm{r}=0.862 \mathrm{IgG}$ と $\mathrm{r}=0.612, \mathrm{r}=$ $0.858 \mathrm{IgM}$ と $\mathrm{r}=0.455, \quad r=0.435$ と有意の正の相関を 認めた。

血清 TTT，ZTTに影響する因子について年齢，肝炎 ウイルスの有無, $\gamma$-globulin, IgG, IgM で多変量解析 を行うと有意な独立因子として両者とも $\mathrm{HCV}$ 感染が挙 げられた（TTT： p =0.042, ZTT： p <0.0001).なお, 無症候性 HCV およU゙ HBV 感染者とも血小板数, 血清 IV型コラーゲン，ヒアルロン酸は正常範囲内にあり两者 で差は認めなかった。

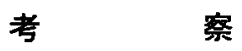

今回の検討で無症候性 HCV 感染者では膠質反応の異

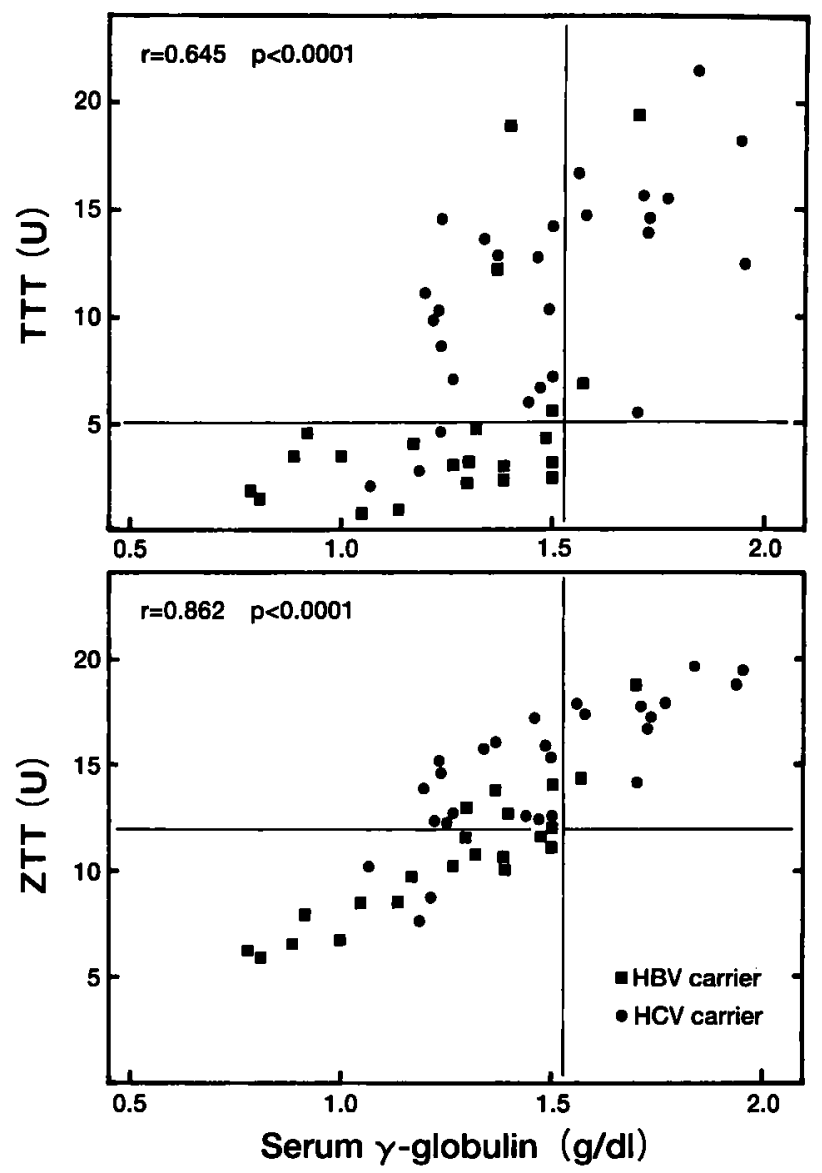

図 1 無症候性 HBV, HCV 感染者における血清 TTT, ZTT と $\gamma^{-}$ globulin との関連

表 1 無症候性HBV，HCV 感染者の臨床検查值

\begin{tabular}{|c|c|c|c|c|}
\hline & $\begin{array}{l}\text { Normal controls } \\
\quad(n=26)\end{array}$ & $\begin{array}{l}\text { HBV carriers } \\
\quad(\mathrm{n}=22)\end{array}$ & $\begin{array}{l}\text { HCV carriers } \\
\quad(\mathrm{n}=27)\end{array}$ & $\begin{array}{c}\text { Significance } \\
\text { (HBV vs HCV) }\end{array}$ \\
\hline Bilirubin (mg/dl) & $0.6 \pm 0.3$ & $0.7 \pm 0.2$ & $0.7 \pm 0.3$ & $\mathrm{p}=0.9512$ \\
\hline $\operatorname{ALP}(\mathrm{IU} / \mathrm{L})$ & $230 \pm 75$ & $190 \pm 40$ & $226 \pm 56$ & $\mathrm{p}=0.1287$ \\
\hline $\operatorname{AST}(\mathrm{IU} / \mathrm{L})$ & $21 \pm 6$ & $20 \pm 4$ & $25 \pm 7$ & $\mathrm{p}=0.0515$ \\
\hline $\operatorname{ALT}(\mathrm{IU} / \mathrm{L})$ & $23 \pm 13$ & $19 \pm 8$ & $24 \pm 9$ & $\mathrm{p}=0.2477$ \\
\hline GGT (IU/L) & $16 \pm 10$ & $11 \pm 4$ & $12 \pm 6$ & $\mathrm{p}=0.9531$ \\
\hline Cholesterol $(\mathrm{mg} / \mathrm{dl})$ & $210 \pm 39$ & $189 \pm 24$ & $188 \pm 32$ & $\mathrm{p}=0.9962$ \\
\hline $\operatorname{ChE}(\mathrm{IU} / \mathrm{L})$ & $173 \pm 36$ & $173 \pm 60$ & $161 \pm 41$ & $\mathrm{p}=0.6586$ \\
\hline Albumin $(g / d l)$ & $4.5 \pm 0.3$ & $4.5 \pm 0.3$ & $4.4 \pm 0.3$ & $\mathrm{p}=0.7956$ \\
\hline TTT (U) & $4.7 \pm 3.9$ & $5.1 \pm 5.1$ & $11.1 \pm 4.9^{* * *}$ & $\mathrm{p}=0.0001$ \\
\hline ZTT (U) & $8.9 \pm 2.7$ & $10.8 \pm 3.1$ & $14.9 \pm 3.1^{* * *}$ & $\mathrm{p}<0.0001$ \\
\hline$\gamma$-globulin $(\mathrm{g} / \mathrm{dl})$ & $1.19 \pm 0.17$ & $1.26 \pm 0.26$ & $1.48 \pm 0.25^{* * *}$ & $\mathrm{p}=0.0055$ \\
\hline $\operatorname{IgG}(\mathrm{mg} / \mathrm{dl})$ & $1,311 \pm 151$ & $1.366 \pm 281$ & $1,613 \pm 267^{* *}$ & $\mathrm{p}=0.0029$ \\
\hline $\operatorname{IgM}(\mathrm{mg} / \mathrm{d} \mathrm{l})$ & $118 \pm 53$ & $141 \pm 77$ & $183 \pm 95^{*}$ & $\mathrm{p}=0.1809$ \\
\hline $\operatorname{IgA}(\mathrm{mg} / \mathrm{dl})$ & $298 \pm 108$ & $272 \pm 78$ & $235 \pm 121$ & $\mathrm{p}=0.4856$ \\
\hline type IV collagen ( $\mathrm{ng} / \mathrm{ml}$ ) & $98 \pm 16$ & $118 \pm 35$ & $112 \pm 20$ & $\mathrm{p}=0.7538$ \\
\hline Hyarulonan (ng/ml) & $36 \pm 22$ & $27 \pm 20$ & $43 \pm 19$ & $\mathrm{p}=0.0638$ \\
\hline Platelet $\times 10^{4}$ & $21.7 \pm 5.0$ & $18.2 \pm 6.5$ & $17.8 \pm 2.7$ & $\mathrm{p}=0.9501$ \\
\hline
\end{tabular}

* $\mathrm{p}<0.05, * * p<0.01, * * p<0.0001$ compared with normal controls. 
常が高率に認められ，この独立因子として HCV 感染が 挙げられた. 従って, 検診などで血清トランスアミナー ゼが正常で膠質反応に異常を認めた場合, $\mathrm{HCV}$ 感染を考 虑する必要がある. 実際, 3,000名の検診で573名にZTT の上昇を認め,このうち 44 名 (7.7\%) が HCV 感染者で あったと報告されている゙2. 無症候性 HCV 感染者で膠質 反応が上昇する理由として 1）潜行する慢性肝疾患の存 在, 2) HCV 感染に伴う免疫反応の克進が考えられる. 無症候性 HCV 感染者の肝組織の報告や血清線維化マー カ一の成績から考之ると後者の可能性が強いと思われる. 事実, HCV 感染者では各種の自己抗体の出現が認められ 宿主の免疫反応が充進していることが示されている31. 肝 生検組織でも無症候性 HBV 感染者に比べて無症候性 HCV 感染者で高頻度にリンパ滤胞が確認されており，
$\mathrm{HCV}$ 感染自体で免疫グロブリン産生が増加し膠質反応が 上昇するものと考之られる。

結語

無症候性 HBV 感染者と異なり, 無症候性 HCV 感染 者では高頻度に血清 TTT，ZTT が増加することが示さ れた．血清線維化マーカーは正常であるので，上昇機序 としては HCV 感染に伴う宿主の免疫反応充進が示唆さ れる。臨床的には安価で簡便な膠質反応が多数例の検診 で HCV 感染者の発見に利用できる可能性が示された。

\section{文}

\section{献}

1) Hoofnagle JH, et al. : Hepatology (1997) 26, 15s-20s. 2）福井 実：北海道医誌 (1995) 70, 69-82.

3) Murakami J, et al. : Hepatology (1999) 30, 143-150. 


\section{2 ）グアナーゼからみた B 型肝炎と C 型肝炎との差異}

本田 浩仁, 久保謙一郎, 豊田 敬生, 崔 学芝

呂広明, 清水 一郎, 伊東 進

キーワード：グアナーゼ(GU)， B 型肝炎，C型肝炎

目的

肝細胞の逸脱䤃素である AST, ALT は半減期や肝内 分布, 細胞内分布等の違いにより肝疾患の病態に応じて 值の出方はそれぞれ異なっている。そこで，さらに特徴 の違う第三の肝細胞逸脱酵素 (グアナーゼ $(\mathrm{GU})^{1-51)}$ を 組み合わせることにより，より正確な肝疾患の病態把握 が可能になるものと思われる。

今回われわれは B 型肝炎と C 型肝炎との差異を明らか にするため，AST，ALTにGUを加えた 3 者間におい てそれぞれの相関関係の特徵につき検討した。

\section{対象および方法}

对象：慢性 B 型肝炎患者 112例。（測定回数 313回） 慢性 C 型肝炎患者 564例。(測定回数 1,854 回)

方法：对象患者において同時測定されたAST, ALT, GU の值について 3 者間でのそれぞれの相関関係を明ら かにする。

\section{結果}

- 慢性 B型肝炎での AST, ALT, GU の 3 者間の相関 係数はほぼ0.85前後と一定している（図 $1 ， 2$ ）.

-慢性C型肝炎での相関係数は AST-ALT 0.784, GU -AST 0.900, GU-ALT 0.747であり，GU-AST で最 も高く,GU-ALTで最も低い結果であった(図 1，2).

- B 型肝炎と C 型肝炎との差異は, GU-ALT 間で最も顕
著に認められた（図 1，2）。

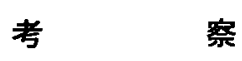

AST, ALT，GUの相関関係の検討により，B型肝炎 とC型肝炎との間の差異は特に GU-ALT 間において顕 著に認められた。この差異の原因にはさまざまな要因が 推測されるがいまだ定かではない．肝炎にはアポトーシ スが深く関与していることが明らかになりつつあるが, 病態の違いによるその割合の差が関与している可能性も 考之られる.また, 逸脱酵素の細胞内分布の違いを反映 した肝細胞障害の起こり方の差にあるとも考之られる。 かつての報告では, 非A非B型肝炎においては GU の免 疫染色において肝細胞の核が染まるものと染まらないも のとが存在することが知られていたが6)，そのことが何か 関倸があるのかもしれない。いずれにしても，第三の肝 細胞逸脱酵素である GU の特徴をさらに明らかにするこ とにより, 各種肝疾患の病態解明の一助になりうる可能 性が期待される。

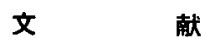

1) Ito $S$, et al : Gastroenterology (1982) 83, 1102.

2) Ito $S$, et al : Hepatology (1986) 6, 990.

3) Ito $S$, et al : Hepatology (1988) 8, 383.

4) 伊東 進, 他：日本臨床（1999） 57 Suppl, 388.

5 ) 本田浩仁, 他：岡山医学会雑誌（2001）113，213.

6) Ito $S$, et al : Acta Histochemica Cytochemica (1986) $19(4), 437$. 

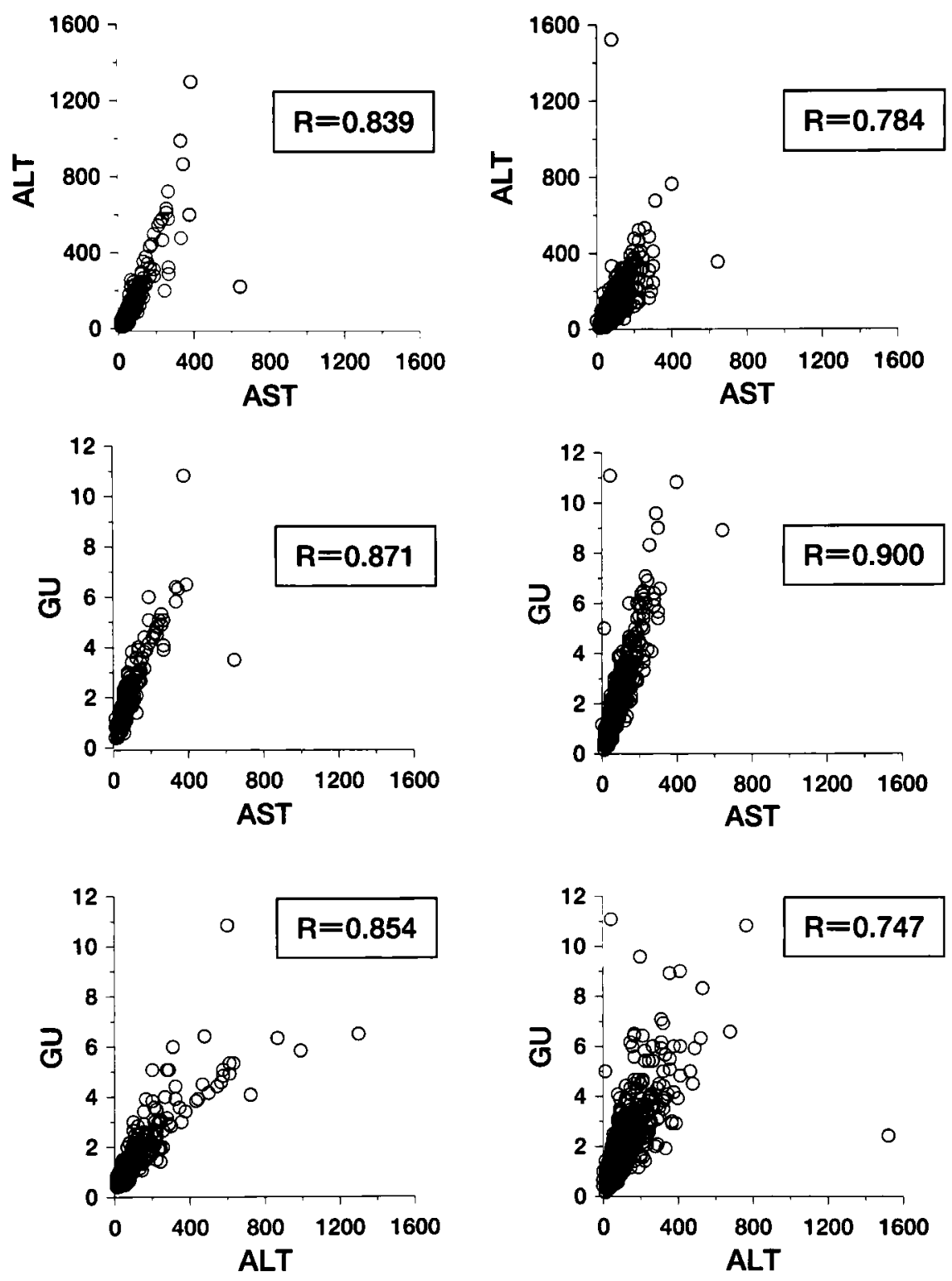

B 型慢性炎虫者



C 型慢性肝炎患者

図 I AST, ALT，GU の相関関係

慢性 B 型肝咨

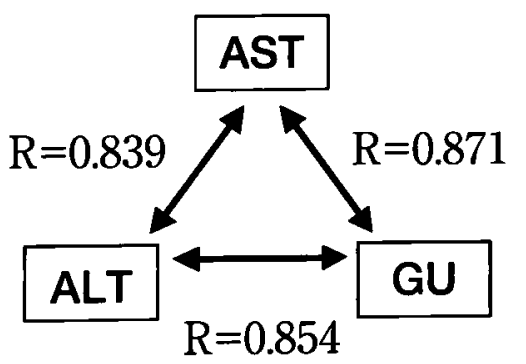

慢性 C 型肝炎

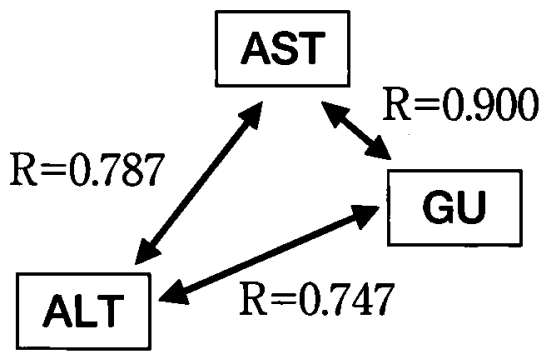

図2 AST, ALT，GU の相関係数の比較 
岡山医学会雑誌 第114巻

August 2002, pp. 217-218

3 ）肝疾患における尿中，肝臓中 8 -hydroxy-2'-deoxyguanosine の意義

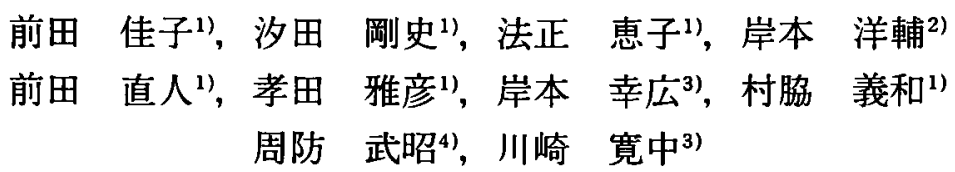

キーワード：8-hydroxy-2'-guanosine, ヒドロキシラジカル, DNA 酸化物質

粕言

8 - hydroxy - 2'-deoxyguanosine ( 8 - OHdG) は DNA 構成要素である deoxyguanosine がヒドロキシラ ジカルなどの活性酸素により生じるDNA 酸化物質であ ク,DNA 酸化障害の指標としての有用性が報告されてい る。今回尿中の $8-O H d G$ 量, 肝組織中の $8-O H d G$ 発現 量を測定し，B型およびC型肝疾患で比較検討した。

\section{対象と方 法}

人間ドッグを受診した20歳代から70歳代の健常者336名, 肝疾患70例 (慢性肝炎18例，肝硬変10例，肝細胞癌42例) で尿中 8-OHdG 量（ng/mg Creatinine）を測定した。ま た慢性肝炎33例, 肝硬変12例, 肝細胞癌28例で肝生検組 織を抗 8-OHdG モノクロナール抗体にて免疫組織学染色 した.

\section{結果}

健常者の尿中 8-OHdG 量は性差を認めなかったが, 非 䝟煙者の平均 $16.5 \mathrm{ng} / \mathrm{mg}$ に対し, 契煙者では $19.6 \mathrm{ng} / \mathrm{mg}$ と 䝟煙者で非喫煙者に化較し有意に增加し，一日の喫煙本 数とは正の相関関係を認めた. 年代別尿中 8-OHdG 量は 20 代，30代，40代，50代，60代，70代で各々平均11.1,
$14.6,16.5,16.2,19.2,21.8 \mathrm{ng} / \mathrm{mg}$ と加龄に伴い增加し た.

肝疾患患者全体では尿中 8-OHdG 量は健常者と変わ らなかったが，50歳未満の肝疾患患者では同年代に比べ て高値を示した，肝疾患の成因別ではC 型がB型に比べ て有意に増加していた(図)。なお B型では平均年齢が58.8 歳，C型では67.7歳でC 型の方が高齢であった。

肝組織中の 8-OHdG 陽性細胞数は慢性肝炎では平均 1000/m²，肝硬変では698/m²，肝細胞癌では1194/m²であ ク，肝細胞癌で肝硬変に比較し有意に増化していた，肝 細胞癌の 8-OHdG 発現を分化度別に検討すると,高分化 型で平均 $876 / \mathrm{mm}^{2}$ ，中分化型では $942 / \mathrm{mm}^{2}$ ，低分化型では $1657 / \mathrm{mm}^{2}$ と，低分化型で発現の増加を認めた．また慢性肝 炎および肝硬変の肝組織の 8-OHdG 発現と肝機能との関 連を検討寸ると，8-OHdG 陽性細胞数はAST, ALT と 正の相関関係を認めた. 疾患別に肝組織中の $8-O H d G$ 発



図 慢性朋疾患の尿中 $8-\mathrm{OHdG} / \mathrm{Cr}$ 员

指導：村脇義和（鳥取大学医学部第二内科）

1) 鳥取大学医学部第二内科

2) 同智床薬理

3) 山陰労災病院内科

4) 鳥取大学保健学科

諭文請求先：鳥取大学医学部第二内科

電話：5859-34-8103 FAX：0859-34-8139 
現を $\mathrm{B}$ 型と $\mathrm{C}$ 型で比較してみると， B 型と $\mathrm{C}$ 型肝疾患に 有意差は認められなかった。

\section{考察と結 論}

今回尿中 8-OHdG 量は肝疾患全体では健常者と変わ らなかったが, 50歳末満の肝疾患患者では増加していた。 さらに成因別では B 型肝疾患に比較し，C型で尿中の 8 -OHdG 量が有意に増加しており, HCV 感染により活性 酸素の増加が推測された。ただし尿中 8-OHdG 量は加齢 とともに増加するので，加齢による影響も考慮される.
肝組織中 8-OHdG 発現は慢性肝炎および肝硬変では AST, ALT に関連して增加し, 肝細胞の壞死炎症反応 を反映していることが示唆された. また肝細胞癌では分 化度と関連し, 肝組織中 8-OHdG 発現は肝細胞癌の悪性 度規定因子としての有用性が示唆された。

\section{文献}

1）斎藤 秀，他：臨床検查（2000） 44，913.

2) Kasai H : Mutation Research (1997) 387, 147.

3) Cooke MS, et al. : FreeRad. Res (2000) 32, 381. 
岡山医学会雑誌 第114巻

August 2002, pp. 219

\section{4 ） B 型慢性肝炎に対するワクチン治療}

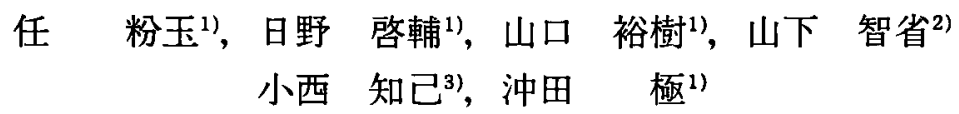

キーワード：B型慢性肝炎, ワクチン治療

緒

これまで $\mathrm{B}$ 型慢性肝炎の治療には，様々な抗ウイルス 片や免疫賦活剂, 副腎皮質ステロイド離脱療法が行われ てきたが、B型慢性肝炎の病態を考慮すれば，最終的に は宿主の免疫応答が決め手になると考えられている ${ }^{11} . \mathrm{B}$ 型慢性肝炎の病態は C 型慢性肝炎に較べて宿主の免疫応 答か強く関与し，ウイルスの增殖形態も episomal のみ でないため, インターフェロン(IFN)やラミブジンに代 表される抗ウイルス剤では完全なウイルスの排除が困難 である。こうした治療の困難を克服するために，近年 B 型慢性肝炎に対する免疫療法のひとつとしてワクチン治 療の基礎的，臨床的検討が報告されているが，その作用 機序は未だに明らかではない，我々はワクチン治療の機 序について prospective に検討したので報告する。

\section{対象と方法}

対象は HBV DNA 陽性の患者13名である．使用した ワクチンはヒト培盖細胞株（huGK-14細胞）由来の沈降 B 型肝炎ワクチン「明乳」で微量のPre-S 2 抗原を含有 する. このワクチン $10 \mu \mathrm{g}$ を毎月一回, 6 力月間投与した. ワクチン治療前, 治療開始後 3 ヶ月， 6 ヶ月，9 个月, 12 月目の患者のへパリン加血液より末梢血単核球 (PBMC) を採取し，磁気ビーズ法により T細胞を分離 した. その後, ワクチンに含有される $\mathrm{HBsAg} と \mathrm{PreS}$

指導：沖田 極（山口大学医学部第一内科）

1）山口大学医学部第一内科

2) 下関厚生病院

3) 周東綕合病院

論文請求先：山口大学医学部第一内科

電話：0836-22-2241 FAX：0836-22-2240
2 ペプチド刺激によるT細胞の Preliferation assay を $\left[{ }^{3} \mathrm{H}\right]$ Thymidine 取り込み法で行った。 また，抗原刺激 後72 96時間後の培養上清中のサイトカイン IL- 2, IL- $4, \mathrm{IL}-10, \mathrm{INF}-\boldsymbol{\gamma}, \mathrm{TNF}-\boldsymbol{\alpha}$ を ELISA 法で測定した.

結果

これまでワクチン治療終了した患者は12名で，そのう ち 4 名の患者において治療開始後 $3 \sim 9$ ヶ月に HBs 抗 原, PreS 2 ペプチドに特異的なT細胞の増殖が認められ, 以後も持続している.この堌殖反応は $\mathrm{CD} 4$ 抗体で有意に 抑制され, CD 8 抗体では殆ど抑制されなかった。抗原特 異的 T細胞の誘導が認められた症例ではワクチン治療後 IFN $-\gamma ， \mathrm{TNF}-\alpha$ の産生能が有意に上昇したが, IL- 4 ， IL-10の産生能は変化しなかった。臨床的治療効果として, ワクチン治療終了した 6 ヶ月目の時点で患者の血清中の HBV DNAの量は治療開始時点と比へて有意に低下した が,トランスアミナーゼ (ALT) の変化には有意な差を 認めなかった．臨床的効果判定については更なる follow up が必要と考えられる.

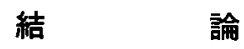

B 型慢性肝炎に対するワクチン治療では, ワクチンに 含有される HBsAg あるいは Pre-S 2 抗原に特異的な $\mathrm{CD} 4$ 陽性細胞の誘導が認められ,これらの細胞のサイト カイン産生能は Th 1 系優位であった. しかし, ワクチ ン治療単独での有意なウイルスの增殖抑制と炎症の鎮静 化を来しうるには限界もあると考えられ，今後抗ウイル ス療法との併用などについて検討を重ねる必要があると 考えられた。



1) 各務伸一：消化器の臨床 (2001) 4, 307 . 